\title{
Article \\ Alfalfa Forage Production and Nutritive Value, Fermentation Characteristics and Hygienic Quality of Ensilage, and Soil Properties after Broiler Litter Amendment
}

\author{
Annesly Netthisinghe ${ }^{1, *(\mathbb{C})}$, Paul Woosley ${ }^{1}$, Naomi Rowland ${ }^{2}$, Todd Willian ${ }^{1}$, Becky Gilfillen ${ }^{1}$ \\ and Karamat Sistani ${ }^{3}$ \\ 1 Department of Agriculture and Food Sciences, Western Kentucky University, Bowling Green, KY 42101, USA; \\ paul.woosley@wku.edu (P.W.); todd.willian@wku.edu (T.W.); becky.gilfillen@wku.edu (B.G.) \\ 2 Department of Biology, Western Kentucky University, Bowling Green, KY 42101, USA; \\ naomi.rowland@wku.edu \\ 3 Food Animal Environmental Systems Research, USDA-ARS, Bowling Green, KY 42101, USA; \\ karamat.sistani@usda.gov \\ * Correspondence: annesly.netthisinghe@wku.edu
}

check for updates

Citation: Netthisinghe, A.; Woosley, P.; Rowland, N.; Willian, T.; Gilfillen, B.; Sistani, K. Alfalfa Forage Production and Nutritive Value, Fermentation Characteristics and Hygienic Quality of Ensilage, and Soil Properties after Broiler Litter Amendment. Agronomy 2021, 11, 701. https://doi.org/10.3390/ agronomy11040701

Academic Editor: Jerome H. Cherney

Received: 23 March 2021

Accepted: 2 April 2021

Published: 7 April 2021

Publisher's Note: MDPI stays neutra with regard to jurisdictional claims in published maps and institutional affiliations.

Copyright: (c) 2021 by the authors. Licensee MDPI, Basel, Switzerland. This article is an open access article distributed under the terms and conditions of the Creative Commons Attribution (CC BY) license (https:// creativecommons.org/licenses/by/ $4.0 /)$.

\begin{abstract}
Recycling broiler litter (BL) nutrients is an important strategy for sustainable forage production. However, BL can contain Clostridia bacteria that can contaminate forages at harvest, resulting in poor ensilage quality and botulism-related animal health risks. A better understanding of the effects of BL amendment on alfalfa (Medicago sativa L.) production and ensiling is beneficial for promoting manure-based alfalfa production. This 2-year study examined the effects of high-level BL (HBL) at $112 \mathrm{~kg} \mathrm{~N} \mathrm{ha}^{-1}$ and low-level (LBL) at $56 \mathrm{~kg} \mathrm{~N} \mathrm{ha}^{-1}$ on alfalfa forage production, fermentation characteristics, and Clostridium botulinum concentrations in silage and haylage produced from $350 \mathrm{~g}$ dry matter (DM) kg-1 forage and $500 \mathrm{~g} \mathrm{DM} \mathrm{kg}^{-1}$ forage respectively, and soil characteristics compared to a control treatment $(\mathrm{CT})$. Results showed that the application of BL did not affect forage production (12.8-13.1 $\mathrm{MG} \mathrm{ha}^{-1}$ ) and nutritive value. The alfalfa produced high forage yield with superior ensilabilty in the second year. The BL application increased soil $\mathrm{NH}_{4}-\mathrm{N}, \mathrm{Ca}, \mathrm{Fe}$, and $\mathrm{B}$, but did not affect fermentation characteristics or Clostridium botulinum concentrations in ensilage. Silage had superior fermentation quality, and Clostridium botulinum concentration was found to be higher than in haylage. Broiler litter fertilization for alfalfa is environmentally safe and has forge production, ensilage fermentation quality, and botulism risks similar to CT.
\end{abstract}

Keywords: alfalfa; broiler litter; forage production; ensiling; soil properties; Clostridia; botulism; silage; haylage

\section{Introduction}

Commercial broiler production generates larger volumes of broiler chicken (Gallus gallus domesticus) litter (a mixture of chicken manure and the bedding materials) for disposal. Broiler litter (BL) contains considerable amounts of $\mathrm{N}, \mathrm{P}, \mathrm{K}$, and other secondary and micro nutrients required for plant growth [1,2] and is of great interest as a source of plant nutrients. Research has shown broiler litter (BL) as an alternative to chemical fertilizers increased crop production including forage dry matter (DM) yield [3], cotton (Gossipium hersetum L.) lint yield [4], and corn (Zea maize L.) grain production [5]. However, frequent application of $\mathrm{BL}$ at high rates has contributed to enrichment of $\mathrm{P}$ and metals such as $\mathrm{Cu}$ and $\mathrm{Zn}$ in the surface soil [6]. Excessive elemental accumulation in surface soil could pose environmental, public health, and agronomic concerns. The increased regulatory pressure aimed at reducing environmental impacts by animal manure application on lands and the introduction of systematic nutrient management planning has made producers reconsider their manure management strategies [7]. Although land application has been 
the key practice of animal manure disposal, many livestock producers do not possess sufficient land areas of row crop or forage grassland to apply manure at agronomic rates or rates complying with the manure management regulatory requirements. In such instances, producers have opted to find alternative crops to receive manure nutrients [8]. Due to superior nutritive value of forage and ability to use for haying, grazing, and conservation, alfalfa (Medicago sativa L.) has become one of the preferred perennial forage legumes among livestock producers [9]. Application of manure to alfalfa would increase the land area available for spreading, thereby decreasing the application rate and lessen the potential environmental and agronomic risks. As a legume, alfalfa typically meets much of its $\mathrm{N}$ requirement through biological $\mathrm{N}_{2}$ fixation and the rest is obtained from soil $\mathrm{N}$ sources and residual fertilizers. Like other legumes, alfalfa uses available soil $\mathrm{N}$ before fixing $\mathrm{N}_{2}$ symbiotically [10]. Research has shown negative effects of $\mathrm{N}$ fertilization on biological $\mathrm{N}_{2}$ fixation [11-15]. Cherney et al. [16] indicated that proportion of plant $\mathrm{N}$ from biological $\mathrm{N}_{2}$ fixation reduced from 55 to $85 \%$ to 13 to $27 \%$ at high $\mathrm{N}$ fertilization rates. In general, legumes including alfalfa have greater $\mathrm{P}, \mathrm{K}, \mathrm{Cu}$, and $\mathrm{Zn}$ requirements than grasses $[17,18]$. There is also evidence for $\mathrm{P}$ and $\mathrm{K}$ fertilization to improve persistence and increased alfalfa forage yield $[19,20]$. Thus, alfalfa can be a potential alternative crop to receive BL and to utilize N, P, K, and micronutrients from BL without overloading them in soil profiles. Accordingly, use of BL nutrients can provide economic and environmental justifications for incorporating into alfalfa forage production.

Ensiling is an important forage conservation strategy that aims at supplying roughage during lean periods, especially in the winter season [21]. Depending on the management practices and prevailing environmental conditions, the dry matter (DM) content at which alfalfa is harvested for ensiling varies from un-wilted to greater than $70 \%[22,23]$. The composition of forage has a great influence on ensiling process, where the water-soluble carbohydrates (WSC) present in plant tissues are fermented anaerobically by lactic acid bacteria primarily to lactic acid. However, forage crude protein $(\mathrm{CP})$ and minerals such as $\mathrm{K}, \mathrm{Ca}$, and $\mathrm{Mg}$ can present negative effects on quality of ensilage by the production of $\mathrm{NH}_{3}$ $\mathrm{N}$ and contributing forage buffer capacity for ensiling, respectively. Forage minerals can buffer the rapid reduction of $\mathrm{pH}$ appropriate for proper fermentation and ensiling. Along with the higher ensilage $\mathrm{pH}$, poor fermentation conditions derived from forage quality characteristics can facilitate the growth and development of Clostridium bacteria responsible for producing undesirable butyric acid (by lactate-fermenting Clostridia), ammonia, amines, $\mathrm{CO}_{2}$, and a variety of acids (by amino acid-fermenting Clostridia) [24]. Clostridia bacteria can be added to soil with manure or can naturally be present in soil. Clostridia bacteria prefer growth conditions that are wet $(<30 \% \mathrm{DM})$ and higher in $\mathrm{pH}(>4.8)$ [24], but do not tolerate high osmotic pressure; thus, they are less likely to dominate in ensilage produced from forages wilted to $\approx 500 \mathrm{~g} \mathrm{~kg}^{-1} \mathrm{DM}$ for ensiling [25].

Clostridium botulinum is a Gram-positive, obligate anaerobic, spore-forming bacteria capable of producing botulinum neurotoxins (BoNTs) that act on nerve endings blocking acetylcholine release. Exposure to high concentrations of BoNTs causes neuroparalytic disease botulism in humans and livestock [26]. Clostridium botulinum can survive for many years in the form of highly resistant spores and can be found in the soil environment [27]. In general Clostridium botulinum numbers are very low on standing forage unless inoculated during handling of crop. High $\mathrm{pH}$ encourages germination of spores and ensiled products [28]. Anaerobic conditions with a protein source, sufficient temperature and moisture, and low acidity are considered suitable growth conditions for C. botulinum. In animal production, these conditions can be found in decaying carcasses and insufficiently acidified silage, and haylage [29]. Land application of BL with parts of chicken carcasses that have died from various causes during production can contain C. botulinum that can contaminate forage at harvesting via soil contact [30]. Ensilage from C. botulinum contaminated forage can be a source of BoNTs causing botulinum in cattle [31]. High concentration of C. botulinum spores in forage in combination with the subsequent poor ensiling conditions promote the growth of C. botulinum and production of BoNTs in ensiled products [32]. 
C. botulinum group III is mainly responsible for botulism in various animal species including farm animals [33]. Seven different types of BoNTs are recognized and designated as types A to G. Type B organisms from group III are responsible for more than $85 \%$ of cases of botulism in cattle and horses in North America [34,35]. Cattle and sheep botulism can also be caused by types A, B, C, D, or D/C mosaic toxin [36]. Because of the high mortality rate associated with botulism outbreaks and problems that could be caused by products originated from affected animals entering the food chain, botulism in farm animals is considered a major economic and public health concern [37].

Despite benefit of supplying nutrients for plant growth, BL amendment to alfalfa forage production can affect environmentally sensitive soil elemental concentrations, forage composition characteristics that are important for ensiling, and health and safety of animals feeding on alfalfa ensilage. Investigations on alfalfa forage production, nutritive value and ensilability of forages, fermentation characteristics and C. botulinum-related animal health risks of alfalfa ensilage, together with soils characteristics after BL amendment are scarce. Better understanding the effects of BL amendment in alfalfa forage production and ensiling systems is important for devising BL nutrients for economical and environmentally sustainable alfalfa forage production, conservation, and utilization. This experiment evaluated three BL treatments substituting $0 \%\left(0 \mathrm{~kg} \mathrm{~N}^{-1}\right.$; control treatment (CT)), 20\% (56 $\mathrm{N} \mathrm{kg} \mathrm{ha}^{-1}$; low -level BL (LBL)), and 40\% (112 $\mathrm{kg} \mathrm{N} \mathrm{ha}^{-1}$; high-level BL (HBL)) of the

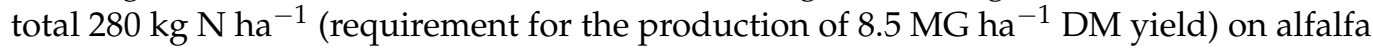
forage yield and nutritive value, fermentation characteristics, and Clostridium botulinum concentrations in alfalfa silage and haylage over two growing seasons.

\section{Material and Methods}

A replicated field experiment was conducted from 2017 to 2018 at the Western Kentucky University Agriculture Research and Education Complex (WKU-AREC), Bowling Green, KY, USA. The soil at the experimental site was Pembroke soil (fine-silty, mixed, active, mesic Mollic Paleudalf) with moderate to high soil P and K levels. The molecular laboratory analyses related to Clostridium botulinum population in BL, soil, and ensiled products was conducted at the Western Kentucky University Biotechnology Center.

\subsection{Management Practices}

The experimental area did not have manure application history and had been planted to tall fescue grass (Festuca arundinacea L.) before initiation of the experiment. After killing the grass stand, soil was tilled and 12 seedbeds measuring 6.0 by $3.0 \mathrm{~m}$ were prepared $3 \mathrm{~m}$ apart. The experimental plots were planted with alfalfa seeds (Ameri Stand 455TQ RR @) in September 2016 at a rate of $20.0 \mathrm{~kg} \mathrm{ha}^{-1}$. It was assumed that alfalfa would produce 8.5 MG ha ${ }^{-1} \mathrm{y}^{-1} \mathrm{DM}$ yield with $20 \%$ crude protein $(16 \% \mathrm{~N})$ and require $272 \mathrm{~kg} \mathrm{~N} \mathrm{ha}^{-1} \mathrm{y}^{-1}$ for the targeted forage production. Accordingly, $3 \mathrm{BL}$ rates, namely, HBL, LBL, and CT, were designed to supplement 40\% (112 $\left.\mathrm{kg} \mathrm{N} \mathrm{ha}^{-1} \mathrm{y}^{-1}\right), 20 \%\left(56 \mathrm{~kg} \mathrm{~N}^{-1} \mathrm{y}^{-1}\right)$, and $0 \%\left(0 \mathrm{~kg} \mathrm{~N} \mathrm{ha}^{-1} \mathrm{y}^{-1}\right)$ of the total rate of $272 \mathrm{~kg} \mathrm{~N} \mathrm{ha}^{-1} \mathrm{y}^{-1} \mathrm{~N}$ through BL nutrients. The nitrogen availability from BL in each year of application was assumed as 50\% [38]. The $3 \mathrm{BL}$ rates, $\mathrm{HBL}, \mathrm{LBL}$, and CT, were tested in a randomized complete block design with 4 replicates. The composition of BL and BL nutrients supplied to HBL, LBL, and CT treatment plots at the beginning of 2 growing seasons are presented in Tables 1 and 2.

The alfalfa growth from the last harvest in summer was harvested in late April-early May 2017 and 2018, and surface spreading of BL occurred thereafter. The assignment of BL treatments to plots was identical in the two years. The HBL and LBL treatments received $112 \mathrm{~kg} \mathrm{~N} \mathrm{ha}^{-1} \mathrm{y}^{-1}(40 \%)$ and $56 \mathrm{~kg} \mathrm{~N} \mathrm{ha}^{-1} \mathrm{y}^{-1}$ (20\%), respectively, from BL, and the CT treatment received no BL or fertilizer $\left(0 \mathrm{~kg} \mathrm{~N} \mathrm{ha}^{-1} \mathrm{y}^{-1}\right)$. The recommended levels of $\mathrm{P}, \mathrm{K}$, $\mathrm{S}$, and B for BL treatments determined by the soil test results from each plot are presented in Table S1. The chemical control of pests on alfalfa crop occurred when their threshold limits were met. 
Table 1. Composition (wet basis) of broiler litter applied in 2017 and 2018.

\begin{tabular}{cccc}
\hline & $\mathbf{2 0 1 7}$ & $\mathbf{2 0 1 8}$ & Average \\
\hline $\mathrm{pH}$ & 6.8 & 7.2 & 7.0 \\
\hline & & $\mathrm{g} \mathrm{kg}^{-1}$ & \\
\hline $\mathrm{DM}$ & 632.6 & 652.0 & 642.3 \\
$\mathrm{Total} \mathrm{N}$ & 28.6 & 32.0 & 30.3 \\
$\mathrm{NH}_{4}-\mathrm{N}$ & 7.3 & 8.6 & 7.9 \\
$\mathrm{NO}_{3}-\mathrm{N}$ & 0.7 & 0.4 & 0.6 \\
$\mathrm{P}$ & 7.6 & 5.5 & 6.5 \\
$\mathrm{~K}$ & 26.3 & 26.1 & 26.2 \\
$\mathrm{Mg}$ & 4.8 & 5.8 & 5.3 \\
$\mathrm{Ca}$ & 20.6 & 18.4 & 19.5 \\
$\mathrm{~S}$ & 10.1 & 6.7 & 8.4 \\
$\mathrm{~B}$ & 0.03 & 0.04 & 0.03 \\
$\mathrm{Zn}$ & 0.3 & 0.4 & 0.3 \\
$\mathrm{Mn}$ & 0.4 & 0.4 & 0.4 \\
$\mathrm{Fe}$ & 0.1 & 0.3 & 0.2 \\
$\mathrm{Cu}$ & 0.3 & 0.2 & 0.3 \\
\hline
\end{tabular}

Table 2. Mean amounts of broiler litter (BL) and BL nutrients added to high-level BL (HBL), low-level BL (LBL), and control treatment (CT) treatment plots during 2017 and 2018.

\begin{tabular}{|c|c|c|c|c|c|c|}
\hline & BL & $\mathbf{N}$ & $\mathbf{P}$ & $\mathbf{K}$ & $\mathrm{S}$ & B \\
\hline & & \multicolumn{5}{|c|}{$\longrightarrow \mathrm{kg} \mathrm{ha}^{-1} \longrightarrow$} \\
\hline \multicolumn{7}{|l|}{2017} \\
\hline HBL & 7672 & 112 & 58 & 202 & 51 & 0.2 \\
\hline LBL & 3836 & 56 & 29 & 101 & 26 & 0.1 \\
\hline $\mathrm{CT}$ & 0 & 0 & 0 & 0 & 0 & 0 \\
\hline \multicolumn{7}{|l|}{2018} \\
\hline HBL & 6850 & 112 & 38.4 & 178 & 68 & 0.2 \\
\hline LBL & 3425 & 56 & 19.2 & 89 & 34 & 0.1 \\
\hline $\mathrm{CT}$ & 0 & 0 & 0 & 0 & 0 & 0 \\
\hline \multicolumn{7}{|c|}{2 year Average } \\
\hline HBL & 7261 & 112 & 48.2 & 190 & 60 & 0.2 \\
\hline LBL & 3630 & 56 & 24.1 & 95 & 30 & 0.1 \\
\hline $\mathrm{CT}$ & 0 & 0 & 0 & 0 & 0 & 0 \\
\hline
\end{tabular}

\subsection{Analysis of Soils and Broiler Litter Nutrients}

Soil sampling occurred periodically during the 2 years of alfalfa production. In each year, initial soil nutrient levels were monitored in late March (1 month before harvesting alfalfa growth from fall) and at the end of each growing season in October. Fifteen soil samples were collected to a depth of $10 \mathrm{~cm}$, mixed thoroughly, and air dried before grinding to pass 2-mm screen. Thereafter, soil samples were analyzed for $\mathrm{pH}$; total soil carbon (TC); total soil $\mathrm{N}(\mathrm{TN})$; nitrate- $\mathrm{N}\left(\mathrm{NO}_{3}-\mathrm{N}\right)$; ammonium- $\mathrm{N}\left(\mathrm{NH}_{4}-\mathrm{N}\right)$; and Mehlich-3 (M-3) extractable $\mathrm{P}, \mathrm{K}, \mathrm{Ca}, \mathrm{Mg}, \mathrm{Zn}, \mathrm{Fe}, \mathrm{Cu}$, and $\mathrm{B}$ contents. Soil $\mathrm{pH}$ was measured using a glass electrode with a 1:1 soil/water ratio. Mehlich-3 [39] extractable P, K, Ca, Mg, Zn, Fe, Cu, and $\mathrm{B}$ concentrations were determined by emission spectroscopy on an inductively coupled argon plasma spectrophotometer (Vista Pro Varian Analytical Instruments, Walnut Creek, CA, USA). The soil $\mathrm{NH}_{4}-\mathrm{N}$ and $\mathrm{NO}_{3}-\mathrm{N}$ contents were determined by $\mathrm{KCl}$ extractions using flow-injection colorimetric analysis with cadmium reduction [40] on an automated analyzer (Lachet Quickchem FIA + 8000 analyzer, Hach, CO, USA). Broiler litter stored under cover for 2 months after removal from broiler houses was obtained from a commercial farm. Visual observation indicated the presence of bone parts of dead chicken in BL, but not the whole dead carcasses. Microwave-assisted acid digestion procedure with inductively coupled argon plasma spectrophotometry (Vista Pro Varian Analytical Instruments, Walnut 
Creek, CA, USA) was used to determine nutrient composition of BL (prepared with 10 grab samples). Nitrogen content in BL and total soil $\mathrm{N}$ and $\mathrm{C}$ contents were determined by Vario Max CN element analyzer (Elementar America Inc., Mt. Laurel, NJ, USA).

\subsection{Forage Harvesting, DM Production, and Nutritive Value Analysis}

The first harvests of alfalfa forage after the BL treatments occurred in late May, and the final harvests took place in late September each year. Harvesting dates were selected when the stands were in late bud-bloom initiation stage. In the first year, 3 forage harvests were possible and a 4-harvest system was implemented in the second year. At each harvest, all border areas $(\approx 0.5 \mathrm{~m}$ wide) around plots were excluded from sampling. Dry matter content and composition of alfalfa forage was determined by harvesting $4 \mathrm{~m}^{2}$ area per plot to a stubble height of $5 \mathrm{~cm}$. Fresh forage weights were determined and then $800-\mathrm{g}$ grab subsamples collected from plots were dried at $60{ }^{\circ} \mathrm{C}$ in a forced air oven for $48 \mathrm{~h}$. until a constant mass was obtained. Forage yield was calculated on a dry weight basis. Dry matter yield of each plot was calculated using fresh weight of forage harvested from $4 \mathrm{~m}^{2}$ area, area harvested, and percentage DM. The dried forage samples were then ground to pass through a 1-mm screen sieve and analyzed for crude protein (CP); acid detergent fiber (ADF); neutral detergent fiber (NDF); water-soluble carbohydrates (WSC); and $\mathrm{P}, \mathrm{K}, \mathrm{Ca}, \mathrm{Mg}$, $\mathrm{Fe}, \mathrm{Zn}$, and $\mathrm{Cu}$ concentrations. Acid detergent and neutral detergent fiber contents were determined by Filter Bag Technique A200 (4-13-11). Crude protein content was measured by combustion of dried ground samples using a CN628 Carbon/Nitrogen Determinator (Leco Corporation, St. Joseph, MI, USA) for N contents and subsequently converted to $\mathrm{CP}$ values. Water-soluble carbohydrate concentrations in forage were determined by incubating forage samples in a $40^{\circ} \mathrm{C}$ bath for $1 \mathrm{~h}$ to extract water soluble carbohydrates using a Thermo Scientific Genesys 10S Vis Spectrophotometer (Thermo Fisher Scientific, Waltham, MA, USA) and acid hydrolysis with sulfuric acid and colorimetric reaction with potassium ferricyanide.

\subsection{Forage Ensiling and Chemical Analysis of Ensilage}

The first and second forage harvests after BL treatments were ensiled in each year. Whole plant alfalfa forage harvested from $2 \times 2 \mathrm{~m}$ areas of each plot were laid on the ground until wilted to $350 \mathrm{~g} \mathrm{~kg}^{-1} \mathrm{DM}$ (for silage) and $500 \mathrm{~g} \mathrm{~kg}^{-1} \mathrm{DM}$ levels (for haylage). To avoid possible cross contamination of forage between the experimental plots, we used separate sickle bar mower blades to harvest forage from each BL treatment plots. In addition, sickle bar mower blade was disinfected with $70 \%$ alcohol, before and after harvesting the replicates of each BL treatment. The moisture levels of alfalfa forage were determined periodically by using a microwave oven [41] until the targeted 350 and $500 \mathrm{~g} \mathrm{~kg}^{-1} \mathrm{DM}$ levels were attained. Alfalfa forages were chopped manually to a length of $5 \mathrm{~cm}$ before packaging. Safety measures avoiding further cross-contamination were adopted during chopping and packaging of forages. The amount of alfalfa forage added to each chamber vacuum packaging pouch for ensiling was adjusted on the basis of moisture level so that air-to-herbage ratio remained constant for all pouches. Accordingly, 2 forage samples weighing $800 \mathrm{~g}\left(350 \mathrm{~g} \mathrm{~kg}^{-1} \mathrm{DM}\right)$ and $560 \mathrm{~g}\left(500 \mathrm{~g} \mathrm{~kg}^{-1} \mathrm{DM}\right)$ were packed in to $35 \times 50 \mathrm{~cm}$ chamber vacuum packaging pouches (4.0-mil) using nitrile gloves. Duplicated packed pouches per plot were prepared for each forage DM regime. The pouches were vacuumsealed immediately after packing. The sealed pouches were allowed to ensile for $60 \mathrm{~d}$ at ambient temperature $\left(20-25^{\circ} \mathrm{C}\right)$ in a closed barn. After ensiling for 60 days, the first set of pouches was analyzed for $\mathrm{pH}$, ammonia-N (NH3-N), lactic acid, and volatile fatty acid (acetic acid, butyric acid, and propionic acid) concentrations. The second set of pouches was used for analyzing C. botulinum concentrations. Water extracts, prepared by mixing a $50 \mathrm{~g}$ sample with $200 \mathrm{~mL}$ deionized water and homogenizing for $1 \mathrm{~min}$ [42], were used to measure $\mathrm{pH}$ by a Thermo Orion Combination Sure-Flow $\mathrm{pH}$ Electrode and Thermo Orion 410 A meter (Thermo Fisher Scientific, Waltham, MA, USA). Aliquot of extract mixed 1:1 ratio with $0.06 \mathrm{M}$ oxalic acid containing $100 \mathrm{ppm}$ trimethylacetic acid (internal standard) 
was injected into a Perkin Elmer Clarus 680 Gas Chromatograph (Perkin Elmer, Waltham, MA, USA) to determine acetic acid, butyric acid, and propionic acid concentrations. The lactic acid concentrations in the samples were measured by injecting aliquot of extract into biochemistry analyzer (YSI Incorporated Life Sciences, Yellow Springs, OH, USA). The ammonium- $\mathrm{N}$ concentrations were determined on extracts using Timberline TL-2800 Analyzer (Timberline Instruments, Boulder, CO, USA). Since Clostridium botulinum was detected only in the ensilage from second cut, their characteristics are presented for the 2 years.

\subsection{Analysis of Clostridium botulinum of Broiler Litter, Soil, and Ensiled Products}

Samples of soil and ensilage originated from each experimental plot or duplicated BL samples were homogenized in a mortar and pestle using liquid nitrogen. Broiler litter samples ( $2 \mathrm{~m}$ old) collected before land application, soil samples collected before applying BL treatments and after the post treatment first and second forage harvests, and ensilage (silage and haylage) of the first 2 forage harvests were analyzed for C. botulinum concentrations. Total DNA was isolated from soil and BL using the Norgen Biotek Soil DNA Isolation kit per kit directions. Total DNA was isolated from $100 \mathrm{mg}$ ensiled sample using a modification of the SDS DNA isolation $[43,44]$. DNA quantity and quality were measured via Nanodrop 2000. Presence of C. botulinum was determined by real-time polymerase chain reaction (RT-PCR) using Taqman Gene Expresssion Master Mix. A total of $50 \mathrm{ng}$ of total DNA was used in qPCR with Taqman Gene Expression Assays custom designed for C. botulinum A/B/E/F and C. botulinum C/D. As Enterococcus is typically found ubiquitously in agronomic samples, a custom-designed assay for Enterococcus sp. and alfalfa species was used as an endogenous control. Due to our study being a presence/absence experiment, Enterococcus amplification was particularly important to demonstrate that each sample was of sufficient quality for RT-PCR, especially in samples that showed an absence of C. botulinum. Pure C. botulinum A DNA was obtained by United States Department of Agriculture permit from ATCC BEI Resources and was used as a positive control. RTPCR was performed on a QuantStudio 3 using Taqman Gene Expression Master Mix.

\subsection{Statistical Analysis}

Statistical analysis was performed by general linear model (GLM) procedure (SPSS.26; IBM Corporation, Armonk, NY, USA). Accumulated total annual forge DM yield and mean nutritive value indices of alfalfa forage were analyzed by two-way ANOVA considering BL treatments and growing season (year) as the 2 factors in the model. Soil characteristics were analyzed by two-way mixed ANOVA, where time of (pretreatment and end season) growing seasons and BL treatment were considered as within-subject and between-subject factors, respectively. Fermentation characteristics and Clostridium botulinum concentrations in the ensilage of the second forage harvests were analyzed separately for the 2 years by two-way ANOVA. In this, ensiling forage DM content $\left(350 \mathrm{~g} \mathrm{DM} \mathrm{kg}^{-1}\right.$, silage; and $500 \mathrm{~g} \mathrm{DM} \mathrm{kg}^{-1}$, haylage) and BL treatment were considered as the 2 factors. Mean separation was performed by Bonferroni pairwise comparison at $p<0.05$.

\section{Results}

\subsection{Environmental Conditions}

The environmental conditions (Table 3; Figures S1-S4) at the experimental site were obtained from the Kentucky Mesonet weather station located at the WKU AREC, 50 m away from the experimental site. The experimental site received 965- and 835-mm rainfall (Vaisala VRG101 All Weather Precipitation Gauge) during the March-October period in 2017 and 2018, respectively. These precipitation amounts exceeded the 30-year normal. Daily average air temperatures (naturally aspirated air temperature; Vaisala HPM60 Temperature Probe) during March-October in 2017 were sub-normal, but the air temperature for the same period in 2018 surpassed the 30-year normal. Daily average soil temperature at $5 \mathrm{~cm}$ depth from March-October ranged from 12.9 to $27^{\circ} \mathrm{C}$ and from 8 to $27^{\circ} \mathrm{C}$ in 2017 and 
2018, respectively. In general, daily average soil temperature at $5 \mathrm{~cm}$ depth increased from March to peak in July and thereafter decreased until December. Daily average soil moisture content (percentage volumetric water content-VWC) varied from 7.9 to $34.4 \%$ in 2017 and from 9 to 39\% in 2018 and showed a trend opposite to soil temperature. Accordingly, VWC decreased from March to August and increased thereafter until December.

Table 3. Monthly precipitation, average daily air temperature, and soil temperature and soil moisture content ( $5 \mathrm{~cm}$ depth) in 2017 and 2018 with 30-year average of the experimental site presented by month.

\begin{tabular}{|c|c|c|c|c|c|c|c|c|c|c|c|c|}
\hline & January & February & March & April & May & June & July & August & September & October & November & December \\
\hline & \multicolumn{12}{|c|}{ Monthly rainfall (mm) } \\
\hline 30-year & 90.3 & 99.0 & 110.3 & 108.5 & 140.3 & 105.0 & 102.5 & 83.3 & 98.3 & 84.5 & 105.5 & 120.0 \\
\hline 2017 & 111.8 & 61.8 & 89.0 & 119.3 & 197.0 & 169.8 & 83.3 & 129.3 & 177.3 & 94.5 & 48.0 & 106.5 \\
\hline \multirow[t]{2}{*}{2018} & 50.0 & 226.8 & 106.5 & 95.5 & 140.0 & 116.5 & 144.8 & 89.0 & 142.8 & 107.8 & 126.5 & 129.0 \\
\hline & \multicolumn{12}{|c|}{ Daily average air temperature $\left({ }^{\circ} \mathrm{C}\right)$} \\
\hline 30-year & 2.0 & 4.3 & 9.0 & 14.1 & 18.9 & 23.7 & 25.7 & 25.0 & 21.0 & 14.7 & 9.0 & 3.6 \\
\hline 2017 & 6.1 & 8.5 & 9.6 & 16.8 & 19.1 & 22.4 & 25.4 & 23.2 & 20.1 & 14.8 & 8.8 & 2.4 \\
\hline 2018 & -0.3 & 4.5 & 7.6 & 10.6 & 22.6 & 25.0 & 25.1 & 24.5 & 22.9 & 15.3 & 5.8 & 5.4 \\
\hline \multicolumn{13}{|c|}{ Daily average soil temperature $\left({ }^{\circ} \mathrm{C}\right)$ at $5 \mathrm{~cm}$ depth } \\
\hline 2017 & 7.1 & 7.8 & 12.9 & 17.2 & 20.2 & 24.3 & 27 & 24.6 & 21.1 & 16.9 & 10.1 & 4.6 \\
\hline 2018 & 1.9 & 7.5 & 8.2 & 11.6 & 21.5 & 25.7 & 27 & 25.2 & 23.5 & 17.2 & 8.1 & 5.9 \\
\hline \multicolumn{13}{|c|}{ Daily average soil moisture (VWC $\%$ ) at $5 \mathrm{~cm}$ depth } \\
\hline 2017 & 26.2 & 24.3 & 18.7 & 17.9 & 19.6 & 13.4 & 13.1 & 7.9 & 14.3 & 22.4 & 34.5 & 34.4 \\
\hline 2018 & 29.2 & 39.9 & 36.5 & 33.6 & 14.7 & 12.2 & 11.2 & 9 & 14.6 & 25.4 & 33.9 & 37.2 \\
\hline
\end{tabular}

\subsection{Alfalfa Forage DM Production and Nutritive Value}

The effects of BL treatments and growing seasons on DM production and nutritive value of alfalfa forage are presented in Table 4 . The BL treatment or BL treatment $x$ growing season (year) effect did not influence forage DM production, nutritive value, and mineral concentrations of alfalfa forage. Growing season (year) significantly $(p<0.05)$ affected forage DM production, CP, WSC, K, Ca, Mg, and Cu contents (Table 4). Mean 2-year DM production ranged from $12.8 \mathrm{MG} \mathrm{ha}^{-1}$ in the LBL to $13.1 \mathrm{MG} \mathrm{ha}^{-1}$ in the HBL treatment. The DM yield accumulation was significantly $(p<0.05)$ higher in 2018 with an extra 6.2 $\mathrm{MG} \mathrm{ha}^{-1}$ compared to the $9.9 \mathrm{MG} \mathrm{ha}^{-1}$ in 2017 . Forage $\mathrm{CP}$, structural carbohydrates (ADF and NDF), and non-structural carbohydrates (WSC) and mineral concentrations of alfalfa did not vary among the BL treatments. The structural carbohydrate levels were similar in the two years, but WSC content was significantly $(p<0.05)$ higher in 2018 than in 2017. Forage mineral concentrations showed a mixed response over the two growing seasons. Forage $\mathrm{P}, \mathrm{Fe}$, and $\mathrm{Zn}$ contents did not change in the two growing seasons. However, there were higher $\mathrm{K}, \mathrm{Ca}$, and $\mathrm{Mg}$ levels and lower $\mathrm{Cu}$ concentration $(p<0.05)$ in 2017 than in the second growing season (2018). 
Table 4. Alfalfa dry matter production and forage quality in 2017 and 2018 by the BL rates.

\begin{tabular}{|c|c|c|c|c|c|}
\hline & \multicolumn{3}{|c|}{ BL Rates } & \multicolumn{2}{|c|}{ Growing Season } \\
\hline & HBL $\ddagger$ & LBL $\S$ & CT II & 2017 & 2018 \\
\hline & \multicolumn{3}{|c|}{$\longrightarrow$ MG ha $^{-1}$} & \multicolumn{2}{|c|}{$\longrightarrow \mathrm{MG} \mathrm{ha}^{-1}$} \\
\hline \multirow[t]{2}{*}{ DM $\left(\mathrm{MGha}^{-1}\right)$} & $13.1 \pm 0.4+$ & $12.8 \pm 0.3$ & $12.9 \pm 0.4$ & $9.9 \pm 0.3 b$ & $16.1 \pm 0.4 \mathrm{a}$ \\
\hline & \multicolumn{3}{|c|}{$\mathrm{g} \mathrm{kg}^{-1}$} & \multicolumn{2}{|c|}{$\mathrm{g} \mathrm{kg}^{-1}$} \\
\hline $\mathrm{CP}$ & $222.6 \pm 1.7$ & $223.5 \pm 1.6$ & $225.5 \pm 1.6$ & $227.9 \pm 1.5 \mathrm{a}$ & $219.1 \pm 1.3 b$ \\
\hline $\mathrm{ADF}$ & $289.1 \pm 2.3$ & $287.2 \pm 2.3$ & $285.3 \pm 2.4$ & $284.7 \pm 1.8$ & $289.7 \pm 1.9$ \\
\hline NDF & $363.6 \pm 2.8$ & $362.8 \pm 2.8$ & $360.5 \pm 2.7$ & $362.7 \pm 3.3$ & $361.9 \pm 3.2$ \\
\hline WSC & $86.5 \pm 1.2$ & $85.0 \pm 1.3$ & $84.7 \pm 1.2$ & $71.7 \pm 1.0 \mathrm{~b}$ & $91.8 \pm 1.2 \mathrm{a}$ \\
\hline $\mathrm{P}$ & $3.0 \pm 0.1$ & $3.1 \pm 0.1$ & $3.1 \pm 0.1$ & $3.1 \pm 0.1$ & $3.1 \pm 0.1$ \\
\hline K & $21.9 \pm 0.6$ & $21.7 \pm 0.6$ & $22.1 \pm 0.7$ & $23.1 \pm 0.5 \mathrm{a}$ & $20.6 \pm 0.4 b$ \\
\hline $\mathrm{Ca}$ & $11.0 \pm 0.2$ & $10.9 \pm 0.2$ & $10.9 \pm 0.2$ & $11.3 \pm 0.1 \mathrm{a}$ & $10.6 \pm 0.2 b$ \\
\hline \multirow[t]{2}{*}{$\mathrm{Mg}$} & $2.2 \pm 0.1$ & $2.3 \pm 0.1$ & $2.3 \pm 0.1$ & $2.4 \pm 0.1 \mathrm{a}$ & $2.1 \pm 0.1 \mathrm{~b}$ \\
\hline & \multicolumn{3}{|c|}{$\longrightarrow \mathrm{mg} \mathrm{kg}^{-1}$} & \multicolumn{2}{|c|}{$-\mathrm{mg} \mathrm{kg}^{-1}$} \\
\hline $\mathrm{Fe}$ & $203.9 \pm 16.4$ & $194.9 \pm 16.1$ & $183.9 \pm 16.1$ & $181.4 \pm 13.5$ & $207.1 \pm 14.4$ \\
\hline $\mathrm{Zn}$ & $23.8 \pm 0.3$ & $23.6 \pm 0.4$ & $23.3 \pm 0.4$ & $23.4 \pm 0.2$ & $23.8 \pm 0.2$ \\
\hline $\mathrm{Cu}$ & $10.1 \pm 0.3$ & $10.2 \pm 0.2$ & $10.1 \pm 0.2$ & $9.7 \pm 0.2 \mathrm{~b}$ & $10.5 \pm 0.2 \mathrm{a}$ \\
\hline
\end{tabular}

+ Mean \pm Standard Error. Numbers with different letters across rows within BL rates and year were significantly different at $p<0.05$. $\ddagger$ HBL: high broiler litter; § LBL: low broiler litter; II CT: control.

\subsection{Effects on Soil Characteristics}

The mean (2-year) soil $\mathrm{pH}$ and elemental concentrations of BL treatments and pretreatment and end seasonal levels across the two growing seasons are presented in Table 5 . The BL treatment $\times$ time of growing season interaction effect existed only for soil $\mathrm{NO}_{3}-\mathrm{N}$ and $\mathrm{B}$ levels. The BL treatment significantly $(p<0.05)$ impacted soil $\mathrm{Ca}$ and Fe contents but none of the other elements. The HBL and LBL contained similar Ca and Fe concentrations and the levels in LBL were similar to the CT. Soil $\mathrm{NH}_{4}-\mathrm{N}$ levels increased significantly $(p<0.05)$ in the first year but did not change in the second year. The majority of the soil elemental concentrations followed same trend with a significant $(p<0.05)$ increase of soil TC, TN, $\mathrm{P}, \mathrm{Ca}, \mathrm{Mg}, \mathrm{Zn}$, and $\mathrm{Cu}$ in the first year. In contrast, soil $\mathrm{K}$ level in the first year remained unchanged, but decreased significantly $(p<0.05)$ in the second year. The soil $\mathrm{NO}_{3}-\mathrm{N}$ concentrations in the spring season of the second year was highest in the HBL and LBL, but the level in the LBL was similar to the CT. Except at the beginning of the experiment, the HBL accounted the highest soil B content, whereas both LBL and CT treatments contained similar soil B levels. 
Table 5. Soil properties after BL fertility treatment during pre- and post-growing seasons of 2017 and 2018.

\begin{tabular}{|c|c|c|c|c|c|c|c|}
\hline & \multicolumn{3}{|c|}{ BL Treatment } & \multicolumn{2}{|c|}{2017} & \multicolumn{2}{|c|}{2018} \\
\hline & HBL $\ddagger$ & LBL $\S$ & CT II & Pre Treatment & Post Season & Pre Treatment & Post Season \\
\hline $\mathrm{n}$ & 4 & 4 & 4 & 12 & 12 & 12 & 12 \\
\hline \multirow[t]{2}{*}{$\mathrm{pH}$} & $6.6 \pm 0.1+$ & $6.5 \pm 0.1$ & $6.5 \pm 0.1$ & $6.4 \pm 0.1$ & $6.6 \pm 0.1$ & $6.5 \pm 0.1$ & $6.4 \pm 0.1$ \\
\hline & \multicolumn{3}{|c|}{$\longrightarrow \mathrm{g} \mathrm{kg}^{-1} \longrightarrow$} & \multicolumn{4}{|c|}{$\longrightarrow \mathrm{g} \mathrm{kg}^{-1} \longrightarrow$} \\
\hline TC & $29.9 \pm 1.5$ & $28.0 \pm 1.3$ & $28.8 \pm 2.5$ & $22.2 \pm 1.6 \mathrm{c}$ & $36.1 \pm 3.8 \mathrm{a}$ & $31.9 \pm 0.7 \mathrm{ab}$ & $27.5 \pm 1.3 \mathrm{abc}$ \\
\hline \multirow[t]{2}{*}{ TN } & $3.0 \pm 0.3$ & $3.0 \pm 0.2$ & $2.9 \pm 0.12$ & $2.5 \pm 0.1 \mathrm{~b}$ & $3.4 \pm 0.3 \mathrm{a}$ & $3.2 \pm 0.7 \mathrm{ab}$ & $2.6 \pm 0.1 \mathrm{~b}$ \\
\hline & \multicolumn{3}{|c|}{$\longrightarrow \mathrm{mg} \mathrm{kg}^{-1} \longrightarrow$} & \multicolumn{4}{|c|}{$\longrightarrow \mathrm{mg} \mathrm{kg}^{-1}$} \\
\hline $\mathrm{NH}_{4}-\mathrm{N}$ & $10.4 \pm 1.4$ & $10.0 \pm 1.4$ & $9.7 \pm 1.3$ & $9.1 \pm 0.4 \mathrm{~b}$ & $18.7 \pm 0.6 \mathrm{a}$ & $6.1 \pm 0.3 \mathrm{c}$ & $6.1 \pm 0.3 c$ \\
\hline $\mathbf{P}$ & $42.1 \pm 7.3$ & $27.54 \pm 5.1$ & $31.0 \pm 6.6$ & $24.2 \pm 3.9 \mathrm{~b}$ & $42.2 \pm 4.6 \mathrm{a}$ & $50.4 \pm 3.3 \mathrm{a}$ & $53.2 \pm 5.4 \mathrm{a}$ \\
\hline $\mathbf{K}$ & $204.6 \pm 14.2$ & $188.3 \pm 12.5$ & $193.5 \pm 11.2$ & $217.0 \pm 7.0 \mathrm{a}$ & $234.3 \pm 12.0 \mathrm{a}$ & $210.9 \pm 12.3 \mathrm{a}$ & $170.1 \pm 6.5 \mathrm{~b}$ \\
\hline $\mathrm{Ca}$ & $2569.7 \pm 152.7 \mathrm{a}$ & $2346.3 \pm 150.2 \mathrm{ab}$ & $2207.7 \pm 120.7 b$ & $2295.5 \pm 107.0 \mathrm{~b}$ & $2762.6 \pm 102.7 \mathrm{a}$ & $2083.8 \pm 114.0 b$ & $2177.7 \pm 93.7 b$ \\
\hline $\mathrm{Mg}$ & $252.3 \pm 8.6$ & $243.1 \pm 7.4$ & $257.3 \pm 8.5$ & $245.3 \pm 5.6 \mathrm{~b}$ & $287.1 \pm 7.4 \mathrm{a}$ & $217.9 \pm 5.5 c$ & $226.2 \pm 5.6 \mathrm{bc}$ \\
\hline $\mathrm{Zn}$ & $7.1 \pm 0.4$ & $6.1 \pm 0.4$ & $5.9 \pm 0.4$ & $5.6 \pm 0.3 \mathrm{~b}$ & $7.7 \pm 0.5 \mathrm{a}$ & $5.7 \pm 0.4 \mathrm{~b}$ & $6.9 \pm 0.6 \mathrm{ab}$ \\
\hline $\mathrm{Fe}$ & $98.2 \pm 3.3 \mathrm{a}$ & $95.0 \pm 3.3 \mathrm{ab}$ & $86.4 \pm 4.1 \mathrm{~b}$ & $101.2 \pm 3.2 \mathrm{a}$ & $95.3 \pm 3.0 \mathrm{ab}$ & $79.8 \pm 2.7 c$ & $87.0 \pm 3.1 \mathrm{bc}$ \\
\hline $\mathrm{Cu}$ & $3.7 \pm 0.2$ & $3.5 \pm 0.2$ & $3.4 \pm 0.1$ & $3.1 \pm 0.1 b$ & $3.9 \pm 0.2 \mathrm{a}$ & $3.1 \pm 0.2 b$ & $3.6 \pm 0.2 \mathrm{ab}$ \\
\hline \multicolumn{8}{|l|}{$\mathrm{NO}_{3}-\mathrm{N}$} \\
\hline LBL & - & - & - & $2.5 \pm 0.5$ & $16.0 \pm 0.9$ & $7.5 \pm 0.5 \mathrm{ab}$ & $9.9 \pm 0.8$ \\
\hline $\mathrm{CT}$ & - & - & - & $3.4 \pm 0.9$ & $14.0 \pm 2.6$ & $5.9 \pm 0.6 \mathrm{~b}$ & $9.4 \pm 0.9$ \\
\hline \multicolumn{8}{|c|}{6.0 .0 .0} \\
\hline HBL & - & - & - & $1.0 \pm 0.1$ & $1.2 \pm 0.1 \mathrm{a}$ & $1.0 \pm 0.1 \mathrm{a}$ & $0.7 \pm 0.1 \mathrm{a}$ \\
\hline LBL & - & - & - & $0.9 \pm 0.0$ & $0.9 \pm 0.0 \mathrm{~b}$ & $0.8 \pm 0.0 \mathrm{~b}$ & $0.5 \pm 0.0 \mathrm{~b}$ \\
\hline $\mathrm{CT}$ & - & - & - & $1.1 \pm 0.2$ & $0.9 \pm 0.0 \mathrm{~b}$ & $0.8 \pm 0.0 \mathrm{~b}$ & $0.5 \pm 0.0 \mathrm{~b}$ \\
\hline
\end{tabular}


times were significantly different at $p<0.05$. ‡ HBL: high broiler litter; § LBL: low broiler litter; II CT: control. 


\subsection{Effects on Nutritive Value of Second Cut Alfalfa Forage and Fermentation Characteristics of Ensiled Products}

For the two years, there was no BL treatment effect or BL treatment $\times$ forage DM content interaction effect on forage $\mathrm{CP}, \mathrm{NDF}, \mathrm{WSC}, \mathrm{Ca}, \mathrm{Mg}$, and $\mathrm{K}$ concentrations important for ensilability of second cut alfalfa forage (Table S3) and fermentation characteristics of resulted ensiled products of the two years (Table 6). The ensilage in 2017 had higher mean lactic and acetic acid levels and lower $\mathrm{NH}_{3}-\mathrm{N}$ concentrations than in 2018. Forage DM content at ensiling appeared to significantly influence fermentation characteristics of ensilage. Although forage DM content at ensiling did not affect the ensilage $\mathrm{pH}$, it was 0.1-0.2 units lower in silage produced with $350 \mathrm{~g} \mathrm{~kg}^{-1} \mathrm{DM}$ forage. Ensiling alfalfa forages as silage (350 $\mathrm{g} \mathrm{DM} \mathrm{kg}^{-1}$ forage) favored the production of high levels of $\mathrm{NH}_{3}-\mathrm{N}$, lactic, acetic, butyric, and propionic acids compared to the haylage produced with $500 \mathrm{~g} \mathrm{DM} \mathrm{kg}^{-1}$ forages. In addition, it was noted that acid levels in both silage and haylage were higher in 2017 than in 2018, except the lower $\mathrm{NH}_{3}-\mathrm{N}$ levels in 2017.

Table 6. Post-ensiled nutritive value of second cut alfalfa forage and characteristics of ensiled products of BL treatments and forage DM regimes.

\begin{tabular}{|c|c|c|c|c|c|}
\hline & \multicolumn{3}{|c|}{ BL Treatment } & \multicolumn{2}{|c|}{ Ensiled Forage DM Content } \\
\hline & HBL $\ddagger$ & LBL $\S$ & CT II & $350 \mathrm{~g} \mathrm{~kg}^{-1}$ & $500 \mathrm{~g} \mathrm{~kg}^{-1}$ \\
\hline & & & & Silage (M1) & Haylage (M2) \\
\hline $\mathrm{n}$ & 4 & 4 & 4 & 12 & 12 \\
\hline \multicolumn{6}{|l|}{ Ensilage 2017} \\
\hline \multirow[t]{2}{*}{$\mathrm{pH}$} & $5.8 \pm 0.1$ & $5.7 \pm 0.0$ & $5.7 \pm 0.1$ & $5.7 \pm 0.0$ & $5.8 \pm 0.1$ \\
\hline & & +2 & $\mathrm{~g} 100 \mathrm{~g}^{-1}$ & +2 & \\
\hline $\mathrm{NH}_{3}-\mathrm{N}$ of total $\mathrm{N}$ & $3.6 \pm 0.4$ & $3.5 \pm 0.3$ & $3.9 \pm 0.9$ & $4.9 \pm 0.7 \mathrm{a}$ & $1.2 \pm 0.1 \mathrm{~b}$ \\
\hline Lactic acid & $1.1 \pm 0.1$ & $1.1 \pm 0.1$ & $0.8 \pm 0.2$ & $1.4 \pm 0.1 \mathrm{a}$ & $0.6 \pm 0.1 \mathrm{~b}$ \\
\hline Acetic acid & $0.3 \pm 0.1$ & $0.2 \pm 0.1$ & $0.3 \pm 0.2$ & $0.5 \pm 0.0 \mathrm{a}$ & $0.3 \pm 0.1 \mathrm{~b}$ \\
\hline Butyric acid & $0.03 \pm 0.0$ & $0.03 \pm 0.0$ & $0.02 \pm 0.0$ & $0.03 \pm 0.0 \mathrm{a}$ & $0.01 \pm 0.0 \mathrm{~b}$ \\
\hline Propionic acid & $0.03 \pm 0.02$ & $0.00 \pm 0.0$ & $0.03 \pm 0.0$ & $0.03 \pm 0.01 \mathrm{a}$ & $0.00 \pm 0.0 \mathrm{~b}$ \\
\hline \multicolumn{6}{|l|}{ Ensilage 2018} \\
\hline $\mathrm{pH}$ & $6.2 \pm 0.2+$ & $5.7 \pm 0.1$ & $5.7 \pm 0.1$ & $5.9 \pm 0.0$ & $6.1 \pm 0.2$ \\
\hline \multicolumn{6}{|c|}{$-\mathrm{g} 100 \mathrm{~g}^{-1} \longrightarrow$} \\
\hline $\mathrm{NH}_{3}-\mathrm{N}$ of total $\mathrm{N}$ & $6.9 \pm 1.1$ & $5.6 \pm 0.6$ & $5.6 \pm 0.4$ & $9.6 \pm 1.1 \mathrm{a}$ & $2.4 \pm 0.2 \mathrm{~b}$ \\
\hline Lactic acid & $0.7 \pm 0.1$ & $0.7 \pm 0.1$ & $0.6 \pm 0.1$ & $0.8 \pm 0.1 \mathrm{a}$ & $0.5 \pm 0.0 \mathrm{~b}$ \\
\hline Acetic acid & $0.6 \pm 0.1$ & $0.6 \pm 0.2$ & $0.3 \pm 0.2$ & $0.9 \pm 0.2 \mathrm{a}$ & $0.1 \pm 0.0 \mathrm{~b}$ \\
\hline Butyric acid & $0.06 \pm 0.02$ & $0.06 \pm 0.02$ & $0.03 \pm 0.0$ & $0.08 \pm 0.02 \mathrm{a}$ & $0.01 \pm 0.02 \mathrm{~b}$ \\
\hline Propionic acid & $0.01 \pm 0.0$ & $0.01 \pm 0.0$ & $0.02 \pm 0.0$ & $0.02 \pm 0.0 \mathrm{a}$ & $0.0 \pm 0.0 \mathrm{~b}$ \\
\hline
\end{tabular}

† Mean \pm Standard Error. Numbers with different letters across rows within forage DM contents for 2017 and 2018 were significantly different at $p<0.05$. $\ddagger$ HBL: high broiler litter; § LBL: low broiler litter; II CT: control.

\subsection{Effect on Occurrence of Clostridium botulinum Serovars}

For both years, Clostridium botulinum serovars A, B, E, and F were observed in the BL-treated and -untreated ensilage and in silage and haylage, representing the two forage DM regimes. Clostridium botulinum serovars C and D were not detected in any of the BL treatments. The Clostridium botulinum serovar concentrations in ensiled products were not affected either by BL treatment or BL treatment $\times$ forage DM content interaction. However, there was a significant difference in Clostridium botulinum serovar concentration between silage and haylage in 2017, but not in 2018 (Table 7). In 2017, Clostridium botulinum serovar 
concentration was significantly higher in silage produced from $350 \mathrm{~g} \mathrm{~kg}^{-1} \mathrm{DM}$ forage (M1) compared to the haylage originated from $500 \mathrm{~g} \mathrm{~kg}^{-1} \mathrm{DM}$ forage (M2).

Table 7. Occurrence of Clostridium botulinum serovars A, B, E, and F in the ensiled products of second cut forage under the two ensiling forage dry matter $(\mathrm{DM})$ regimes and BL treatments.

\begin{tabular}{|c|c|c|c|c|c|}
\hline & \multicolumn{3}{|c|}{ BL Rates } & \multicolumn{2}{|c|}{ Ensiled Forage DM Content } \\
\hline & HBL $\ddagger$ & LBL $\S$ & CT II & $350 \mathrm{~g} \mathrm{~kg}^{-1}$ & $500 \mathrm{~g} \mathrm{~kg}^{-1}$ \\
\hline & & & & Silage (M1) & Haylage(M2) \\
\hline $\mathrm{n}$ & 4 & 4 & 4 & 12 & 12 \\
\hline & \multicolumn{5}{|c|}{$\longrightarrow$ ng DNA 100 g sample $^{-1}$} \\
\hline 2017 Harvest 2 & $0.043 \pm 0.01 \dagger$ & $0.006 \pm 0.1$ & $0.002 \pm 0.1$ & $0.029 \pm 0.002 \mathrm{a}$ & $0.003 \pm 0.0 \mathrm{~b}$ \\
\hline 2018 Harvest 2 & $0.013 \pm 0.005$ & $0.009 \pm 0.005$ & $0.002 \pm 0.005$ & $0.016 \pm 0.005$ & $0.0 \pm 0.0$ \\
\hline
\end{tabular}

† Mean \pm Standard Error. Numbers with different letters across rows within BL rates and ensiled moisture content were significantly different at $p<0.05$. $\ddagger$ HBL: high broiler litter; § LBL: low broiler litter; II CT: control.

\section{Discussion}

Change in forage DM yield or forage nutritive value as measured by $\mathrm{CP}$, structural and water-soluble carbohydrate, and mineral concentrations were not observed with the supply of BL. The DM yield and CP content results corroborates earlier reports on alfalfa response to addition of $112 \mathrm{~kg} \mathrm{~N} \mathrm{ha}^{-1} \mathrm{~N}$ by dairy manure or swine slurry [45-47]. Research into the manure-based alfalfa forage production has stressed the importance of manure to supply $\mathrm{P}$ and $\mathrm{K}$ requirements for better forage production [48]. In this regard, Schmitt et al. [49] and Mathers et al. [50] indicated that effects of manure application on forage DM yield and herbage $\mathrm{N}$ removal was more evident in soils with low $\mathrm{P}$ and $\mathrm{K}$ fertility. This experiment was conducted in a soil with moderate $\mathrm{P}$ levels $\left(20-50 \mathrm{mg} \mathrm{kg}^{-1}\right)$ and high $\mathrm{K}$ concentrations (160-210 mg kg${ }^{-1}$ ), which exceeded the $30 \mathrm{mg} \mathrm{P} \mathrm{kg}^{-1}$ and $150 \mathrm{mg} \mathrm{K} \mathrm{kg}^{-1}$ recommended optimal levels for alfalfa production in Kentucky [51]. The 12.8-13.1 MG ha-1 average DM yield obtained in this experiment by supplying $0-112 \mathrm{~kg} \mathrm{~N}^{-1}$ was comparable to the $12 \mathrm{Mg} \mathrm{ha}^{-1} \mathrm{DM}$ yield reported by Daliparthy et al. [45] after supplying similar amounts of $\mathrm{N}$ by swine slurry.

Alfalfa, as a legume, can fulfill most of its nitrogen requirement from symbiotic $\mathrm{N}$ fixation. In alfalfa, as $\mathrm{N}_{2}$ fixation process does not begin immediately upon plant emergence, it would be beneficial to fertilize alfalfa with $\mathrm{N}$ fertilizer [52]. However, the results of this experiment did not support such a scenario and showed no BL treatment $\mathrm{x}$ year interaction effect. In addition, achievement of greater $\mathrm{N}$ uptake among the BL treatments was not evident in this experiment supplying $0-112 \mathrm{~kg} \mathrm{~N} \mathrm{ha}^{-1}$. Herbage $\mathrm{N}$ removal calculated by multiplying herbage $\mathrm{DM}$ yield by $\mathrm{N}$ concentration revealed that alfalfa crop without any applied $\mathrm{N}$ accumulated $465 \mathrm{~kg} \mathrm{~N}^{-1}$ from $\mathrm{N}_{2}$ fixation or mineralization compared to the $457 \mathrm{~kg} \mathrm{~N} \mathrm{ha}^{-1}$ and $466 \mathrm{~kg} \mathrm{~N} \mathrm{ha}^{-1}$ in the LBL and HBL treatments, respectively. The $\mathrm{N}$ uptake results exceeded Daliparthy et al. [45] who reported 347 and $354 \mathrm{~kg} \mathrm{ha}^{-1} \mathrm{y}^{-1} \mathrm{~N}$ uptake with $12 \mathrm{MG} \mathrm{ha}{ }^{-1} \mathrm{DM}$ yield after application of swine slurry $\left(0\right.$ and $\left.112 \mathrm{~kg} \mathrm{~N} \mathrm{ha}^{-1}\right)$, but were similar to the results of Schertz and Miller [53] who reported $482 \mathrm{~kg} \mathrm{~N} \mathrm{ha}^{-1}$ and $534 \mathrm{~kg} \mathrm{~N} \mathrm{ha}^{-1}$ alfalfa after 0 and $224 \mathrm{~kg} \mathrm{~N} \mathrm{ha}^{-1} \mathrm{~N}$ fertilization, respectively. We conclude that non-responsive DM production and forage $\mathrm{CP}$ contents among the BL treatments could be attributed to the high $\mathrm{P}$ and $\mathrm{K}$ fertility of soils. The present study showed an additional 6.2 MG ha ${ }^{-1}$ forage DM yield in the second year compared to the year of establishment. This result agreed with Suzuki [19], who reported comparatively low DM production in the year of establishment and increased DM yield in the second and third years, probably due to increased shoot number plant ${ }^{-1}$. In addition, the above-normal and well-distributed precipitation (Table 3 ) and residual fertility from preceding growing season could also have contributed to the additional forage cut and higher mean forage DM yield achieved in the second year. 
Forage mineral concentrations have a significant control over the ensilability of forage. The alfalfa forage $\mathrm{P}$ and $\mathrm{K}$ concentrations in this experiment reflected an adequate status of soil fertility with $\mathrm{P}>3 \mathrm{~g} \mathrm{~kg}^{-1}$ and $\mathrm{K}, 14-30 \mathrm{~g} \mathrm{~kg}^{-1}$ [54]. The BL application did not influence forage $\mathrm{P}$ and $\mathrm{K}$ levels but contained $\mathrm{K}$ levels (21.2-22.9 vs. $6.1 \mathrm{~g} \mathrm{~K} \mathrm{~kg}^{-1}$ ) higher than and P levels ( 3.2 vs. $12.7 \mathrm{~g} \mathrm{P} \mathrm{kg}^{-1}$ ) lower than Suzuki [19]. Given the adequate level of $\mathrm{N}$ for plant growth, alfalfa can be a luxury consumer of $\mathrm{K}$ [55]. However, luxury consumption of $\mathrm{K}$ was not evident in this experiment and forage $\mathrm{K}$ concentrations of $\mathrm{BL}$ treatments were below the $25 \mathrm{~g} \mathrm{~kg}^{-1}$ threshold, causing metabolic health problems in non-lactating cows [56]. The BL application at low BL rates for alfalfa production in soils with moderate-to-high $\mathrm{P}$ and $\mathrm{K}$ fertility does not pose risks of K-related metabolic health problems for livestock.

There was no comparative advantage of applying BL over the control treatment in regard to the forage $\mathrm{CP}, \mathrm{ADF}$, and NDF contents. Only minor differences of $\mathrm{CP}, \mathrm{ADF}$, and NDF levels were noticed as a consequence of the BL application. The forage $\mathrm{CP}$ (198-230 $\left.\mathrm{g} \mathrm{kg}^{-1}\right)$, ADF (262-308 $\left.\mathrm{g} \mathrm{kg}^{-1}\right)$, and NDF (357-399 $\mathrm{g} \mathrm{kg}^{-1}$ ) contents reported in this experiment was comparable to the other works those supplied similar amounts of manure N [47]. However, the negative effects of manure application on ADF and $\mathrm{ADF}$ contents and the advantage of manure application for increased forage $\mathrm{CP}$ content indicated by Coblentz et al. [47] was not observed in this experiment. Given the same amount of $\mathrm{N}\left(112 \mathrm{~kg} \mathrm{ha}^{-1}\right)$ through two different manure sources, dairy manure and broiler litter, the different trends observed for $\mathrm{CP}, \mathrm{ADF}$, and NDF could be attributed to the variation in availability of nutrients and soil fertility status between the two experiments. Min et al. [57] indicated that manure $\mathrm{N}$ application rates even $>400 \mathrm{~kg} \mathrm{~N} \mathrm{ha}^{-1}$ did not alter forage ADF and NDF contents compared to the treatment without manure. This experiment, which supplied $0 \mathrm{~kg} \mathrm{~N} \mathrm{ha}^{-1}$ in the CT and $112 \mathrm{~kg} \mathrm{~N}^{-1}$ in the HBL, also showed similar results with no difference in ADF and NDF among the BL treatments. The water-soluble carbohydrate (WSC) in forages is important for providing substrate for microbial fermentation during ensiling. Along with the forage minerals, WSC concentration can be defined as indicators of forage ensilability. Manure application has been reported to cause negative effects on forage WSC content where higher levels were detected in control treatment compared to the alfalfa forage receiving $108 \mathrm{~kg} \mathrm{ha}^{-1}$ manure $\mathrm{N}$ [47]. Contrasting results noticed in this experiment showed that increasing $\mathrm{N}$ supply by BL amendment did not change WSC concentration in alfalfa forage but had WSC levels $\left(84.7-86.5 \mathrm{~g} \mathrm{~kg}^{-1}\right)$ higher than in other studies $[25,47,58]$. Along with $\mathrm{K}, \mathrm{Ca}$ and $\mathrm{Mg}$ in forage contribute to the buffer capacity of ensiling forage. Although Buxton and O'Kiely [59] reported that manure application may reduce the buffering capacity of the pre-ensiled crops, results from this experiment did not show that $\mathrm{BL}$ amendment altering forage $\mathrm{K}, \mathrm{Ca}$, and $\mathrm{Mg}$ concentrations. However, the BL treatments resulted in much higher forage $\mathrm{K}\left(22 \mathrm{~g} \mathrm{~kg}^{-1}\right)$, $\mathrm{Ca}\left(11.0 \mathrm{~g} \mathrm{~kg}^{-1}\right)$, and $\mathrm{Mg}\left(2.3 \mathrm{~g} \mathrm{~kg}^{-1}\right)$ concentrations than Suzuki [19] and lower levels than Lloveras et al. [46]. Previous studies have shown that BL application, especially at high rates, elevated $\mathrm{Cu}$ and $\mathrm{Zn}$ levels in soils $[6,60]$ and in forage [61]. However, with the low $\mathrm{BL}$ application rates such an increase of forage $\mathrm{Fe}, \mathrm{Cu}$, and $\mathrm{Zn}$ contents were not observed in this experiment. Alfalfa forage from BL treatments contained Fe concentration higher than Suzuki [19] and Lloveras et al. [46], Cu level comparable to Lloveras et al. [46], and $\mathrm{Zn}$ levels exceeding Suzuki [19]. The probable cause of differences in forage mineral concentration among the experiments could be the variations in forage productions [62]. Although, manure application has increased nutrient uptake by alfalfa crop $[63,64]$, in this experiment, neither forage mineral concentrations nor mineral uptake were altered by the BL application. A probable cause for this outcome could be the low amounts of BL applied. Age of alfalfa plant stands has reported affecting forage composition mainly due to increased forage DM yield [62]. According to Suzuki [19], forage WSC and CP concentrations did not change by age in young plant stands ( $<3$ years). Contradicting Suzuki [19], this experiment showed a significant increase in mean forage WSC and CP contents in the second year of growth. The enhanced forage production in 2018 diluted 
plant $\mathrm{K}$ and $\mathrm{Ca}$ concentration [62]; increased $\mathrm{Mg}$ and $\mathrm{Cu}$ contents; and had no effect on $\mathrm{P}$, $\mathrm{Fe}$, and $\mathrm{Zn}$ concentrations.

All pretreatment soil elemental concentrations did not show any significant spatial variability among the plots (Table S3). Soil $\mathrm{pH}$ above 6.4 is preferred for alfalfa production, and all soils of this experiment met this threshold value. In general, BL application has shown decreasing soil acidity by addition of Ca compounds [3,62]. However, in this experiment, BL application did not result in such an increase of soil $\mathrm{pH}$. We assumed that the low amounts of $\mathrm{Ca}$ added through $\mathrm{BL}$ treatments could have been inadequate to induce a change in soil $\mathrm{pH}$. Soil $\mathrm{N}$ level after manure amendment is a significant environmental concern because of excess $\mathrm{N}$ in the soil system. Previous studies have documented that BL application to forage grasses increased soil organic matter, $\mathrm{N}$, and macro and micro soil elements $[3,65]$. In addition, it was shown that $\mathrm{N}$ removal by alfalfa is positively correlated with forage yield [43]. With similar DM yields (Table 5), all the BL treatments extracted the same amounts of $\mathrm{N}$ and resulted in similar soil $\mathrm{N}$ levels. The BL application also did not result in the expected increase of soil TC content. The different trends observed for soil TN and TC contents could have been due to the low BL rates adopted and the short duration (2 years) of the experiment. Of the two growing seasons, soil $\mathrm{C}$ and $\mathrm{N}$ accumulation occurred only in the year of establishment. There was higher soil temperatures and soil moisture levels during the summer 2017 compared to the 2018 (Table 3). We presume that higher mineralization of organic fractions of BL might have contributed to accumulation of soil $\mathrm{N}$ and $\mathrm{C}$ in 2017. Further, despite high precipitation, loss of soil TC and TN concentrations over the winter season in between the two years were not detected in this experiment.

The $\mathrm{NH}_{4}-\mathrm{N}$ in BL-amended soils can be derived directly from the inorganic BL fractions and from mineralization of organic fractions. The different rates of BL applications along with the varying levels of biological $\mathrm{N}_{2}$ fixation resulted in similar soil $\mathrm{NH}_{4}-\mathrm{N}$ levels among the BL treatments. Forage DM production appeared to influence soil $\mathrm{NH}_{4}-\mathrm{N}$ content in the two years. The low forage DM production in 2017 created a low demand for soil $\mathrm{NH}_{4}-\mathrm{N}$ and caused accumulation of soil $\mathrm{NH}_{4}-\mathrm{N}$. Conversely, the higher soil $\mathrm{NH}_{4}-\mathrm{N}$ demand in 2018 might have been compensated by mineralization of BL from the current and preceding year without altering the soil concentration. Moreover, it was noted that high precipitation (Table 3 ) in the winter season caused a significant loss of $\mathrm{NH}_{4}-\mathrm{N}$. The soil $\mathrm{NO}_{3}-\mathrm{N}$ levels is a significant concern as it can contaminate surface and ground water sources. Schmitt et al. [49] reported that application of manure to alfalfa did not increase soil ${ }_{3}-\mathrm{N}$ after a 2-year period. According to Schmitt et al. [49] greatest soil $\mathrm{NO}_{3}-\mathrm{N}$ accumulation in plots receiving manure occurred $30-50 \mathrm{~d}$ after application, and after that, $\mathrm{NO}_{3}-\mathrm{N}$ levels continually decreased throughout the summer to the end of the growing season. In the 2-year experimental period, we also noticed similar results where end seasonal mean soil $\mathrm{NO}_{3}-\mathrm{N}$ concentrations were not different among the BL treatments. Forage production showed impacting soil $\mathrm{NO}_{3}-\mathrm{N}$ as well. The higher end seasonal soil $\mathrm{NO}_{3}-\mathrm{N}$ levels of $\mathrm{BL}$ treatments detected in the first year could have been due to the low $\mathrm{DM}$ production. This experiment reported soil $\mathrm{NO}_{3}-\mathrm{N}$ levels higher than $2.5 \mathrm{mg} \mathrm{kg}^{-1}$ as reported by Daliparthy et al. [45] for dairy manure supplying $112 \mathrm{~kg} \mathrm{~N} \mathrm{ha}^{-1}$ similar to the HBL treatment.

Lloveras et al. [46] showed that swine manure application at low rates $\left(85-102 \mathrm{~kg} \mathrm{~N} \mathrm{ha}^{-1}\right)$ to alfalfa soils either with high or low $\mathrm{P}$ and $\mathrm{K}$ fertility did not increase mean N, P, K, Ca, $\mathrm{Mg}, \mathrm{Cu}, \mathrm{Zn}$, and Fe concentrations during the second and third years of production. The results for soil $\mathrm{Ca}$ and Fe concentrations of this experiment deviated from Lloveras et al. [46], and reported significantly $(p<0.05)$ higher levels of $\mathrm{Ca}$ and Fe in the HBL soils than the $\mathrm{CT}$ and similar to the LBL. However, no difference in soil Ca and Fe levels between the HBL and CT was noticed. Probably the higher initial soil fertility levels of this experiment may have induced HBL soils to retain higher levels of $\mathrm{P}, \mathrm{K}, \mathrm{Mg}, \mathrm{Zn}$, and Fe than $16 \mathrm{mg} \mathrm{P} \mathrm{kg}^{-1}, 153 \mathrm{mg} \mathrm{K} \mathrm{kg}^{-1}, 127 \mathrm{mg} \mathrm{Mg} \mathrm{kg}^{-1}, 4 \mathrm{mg} \mathrm{Zn} \mathrm{kg}^{-1}$, and $39 \mathrm{mg} \mathrm{kg}^{-1}$ reported for swine slurry-applied (108 $\mathrm{kg} \mathrm{N} \mathrm{ha}^{-1}$ ) alfalfa soils [46]. On average, the HBL annually received $0.2 \mathrm{~kg} \mathrm{~B} \mathrm{ha}^{-1}$, twice as much as the LBL and BL application, significantly $(p<0.05)$ 
increasing soil B level in the HBL treatment compared to the LBL and CT treatments across the two growing seasons.

In a soil with moderate-to-high initial $\mathrm{P}$ and $\mathrm{K}$ fertility, mean soil TC, TN, $\mathrm{NH}_{4}-\mathrm{N}_{\text {, }}$ $\mathrm{P}, \mathrm{Ca}, \mathrm{Mg}, \mathrm{Zn}$, and $\mathrm{Cu}$ levels increased across the first growing season, but not in the second season. In contrast, soil $\mathrm{K}$ level remained unchanged in the first growing season but depleted in the second season. Alfalfa is known to have a greater demand for $\mathrm{K}$ than $\mathrm{P}$. The increased forage production in the second growing season (16.1 vs. 9.9 MG ha ${ }^{-1}$ ) might have induced higher uptake of $\mathrm{K}$ depleting the soil $\mathrm{K}$ level. The final $\mathrm{P}$ levels observed after the two growing seasons was twice as high as the initial pretreatment level. Soil elemental concentrations except $\mathrm{P}$ decreased during the winter between the two growing seasons. Of the total $1594 \mathrm{~mm}$ precipitation that occurred between March 2017 and March 2018, $33.7 \%$ (538 mm) was received from November 2017 to March 2018 (Table 3) when plants are less active with regard to nutrient uptake. As such, we presume that the decrease in soil elemental level during the winter season could have been associated with leaching and runoff losses. On average, 2 years of BL amendment at $0-112 \mathrm{~kg} \mathrm{~N}^{-1}$ rate significantly $(p<0.05)$ increased mean P $(119 \%)$ level and caused depletion of soil $\mathrm{NH}_{4}-\mathrm{N}(32 \%), \mathrm{K}$ $(21 \%)$, and $\mathrm{Fe}(14 \%)$ concentrations. After 2 years of alfalfa forage production, mean soil $\mathrm{P}$ and $\mathrm{K}$ concentrations of BL treatments represented adequate levels.

Clostridia contamination of forage by contact of manured soil at harvest can result in deleterious effects on nutritional quality of ensilage and animal health $[59,66]$. The ensilability of forages is generally reflected by WSC and mineral concentrations. The legume forages have low WSC concentration and high buffering capacity with elevated levels of $\mathrm{K}, \mathrm{Ca}$, and $\mathrm{Mg}$ concentrations [9]. Both factors can be deemed to hinder the production of high-quality ensiled products [19]. McDonald et al. [19] reported that $70 \mathrm{~g} \mathrm{~kg}^{-1} \mathrm{WSC}$ is required in forage for rapid and deep fermentation and to produce high-quality ensilage. In this experiment, alfalfa forage from all the BL treatments contained sub-optimal levels of WSC (45-47 $\mathrm{g} \mathrm{kg}^{-1}$ ), but higher than the previous reported 34-39 $\mathrm{g} \mathrm{kg}^{-1}$ [58]. The alfalfa forage presented a buffer capacity comparable to Lloveras et al. [46], with 17.2-26.5 $\mathrm{g} \mathrm{kg}^{-1}$ $\mathrm{K}, 10.2-12.7 \mathrm{~g} \mathrm{~kg}^{-1} \mathrm{Ca}$, and 1.9-2.6 $\mathrm{g} \mathrm{kg}^{-1} \mathrm{Mg}$. However, alfalfa forage contained higher mineral concentrations $\left(8.4 \mathrm{~g} \mathrm{~kg}^{-1} \mathrm{~K}, 5.1 \mathrm{~g} \mathrm{~kg}^{-1} \mathrm{Ca}\right.$, and $1.5 \mathrm{~g} \mathrm{~kg}^{-1} \mathrm{Mg}$ ) than found in manure-fertilized tall fescue grass (Festuca arundinacea L.) [67].

High buffering ensilage systems generally demand more carbohydrates for deep fermentation necessary to preserve plant material effectively. In this experiment, we noticed relatively low levels of forage WSC in all the BL treatments (Table 7) that might have restricted the deep fermentation. As a result, ensilage had a relatively high $\mathrm{pH}$ (5.7-5.8). Gordon et al. [22] indicated that although $\mathrm{pH}$ is generally high and only small amounts of lactic acid is developed, a high chemical quality of ensilage can still be achieved by low levels of undesirable constituent. Mahanna and Chase [68] and Rammer and Lingvall [66] defined the undesirable constituents, butyric acid $>50 \mathrm{~g} \mathrm{~kg}^{-1}$ and $\mathrm{NH}_{3}-$ $\mathrm{N}<100 \mathrm{~g} \mathrm{~kg}^{-1}$, in good quality ensilage. Accordingly, this experiment produced high quality ensilage with butyric acid and $\mathrm{NH}_{3}-\mathrm{N}$ levels lower than the thresholds. The high $\mathrm{pH}$ and low butyric acid and $\mathrm{NH}_{3}-\mathrm{N}$ concentrations indicated the occurrence of restricted fermentation during ensiling. The low WSC contents and high levels of minerals in alfalfa forage could explain the occurrence of restricted fermentation. The restricted fermentation in ensilage was more evident in the 2018 than in 2017, and was indicated by high pH and butyric acid levels and low acetic acid concentration in 2018. Despite the fact that WSC contents between the two forage harvests were similar (Table S3), there were higher mineral concentrations in the 2018 forage (Table S3). The strong buffer action of 2018 forage may have avoided fast and deep fermentation, resulting in poorer silage quality characteristics than in 2017. It appeared that increased forage CP content (2018: 257-262 vs. 2017: $179-173 \mathrm{~g} \mathrm{~kg}^{-1}$ ) contributed to high-ensilage $\mathrm{NH}_{3}-\mathrm{N}$ levels in 2018. Manuring has shown increased Clostridium spores [69], but in this experiment, butyric acid level—the main end product of Clostridia fermentation-were not different among the BL treatments. It has been amply demonstrated that $\mathrm{CP}$ and inorganic ions in pastures may be increased 
by fertilization. However, results from this experiment indicated that alfalfa forage quality characteristics that are important for ensilability were not altered by the BL application. We conclude that despite restricted fermentation, ensiling alfalfa forage after fertilization of BL at low rates would result in ensilage with good fermentation characteristics.

The DM level of forages at ensiling is a major concern as it could affect the level of fermentation [70] and has a control over undesirable ensilage fermentation especially by Clostridia [31]. The high forage DM levels has reduced the growth rate of lactic acid bacteria and hindered rate of acid production $[70,71]$. Although lactic acid bacteria cannot ferment complex carbohydrates in the plant [19], plant enzymes are capable of hydrolyzing hemicellulose [72] and starch [73] to provide additional carbohydrates for fermentation. Higher forage DM content at ensiling presents negative effects on plant respiration rate and plant enzyme activities responsible for hydrolyzing complex carbohydrates. Thus, Kibe et al. [71] concluded that elevated forage DM content at ensiling would reduce the amount of fermentation, produce low concentrations of lactic acid, and result in a higher final $\mathrm{pH}$ than typically expected. Contrasting results by Gordon et al. [22] and Muck [74] indicated that, even though the rate of fermentation may vary due to the limited availability of substrate levels, there can be little difference in final $\mathrm{pH}$ and acid production within a certain DM range. Gordon et al. [22] defined over the forage DM range of 200-530 $\mathrm{g} \mathrm{kg}^{-1}(20-53 \%)$; ensilage $\mathrm{pH}$ remained constant with small difference in lactic acid concentration. The results from this study, which employed a similar DM regime, agreed with Gordon et al. [22] with regard to the $\mathrm{pH}$, but reported significantly different ensilage acid levels between the two forage DM regimes, 350 and $500 \mathrm{~g} \mathrm{~kg}^{-1} \mathrm{DM}$. In agreement with Kibe et al. [71] and Pitt et al. [70], we found that silage from $500 \mathrm{~g} \mathrm{DM} \mathrm{kg}^{-1}$ forage had significantly $(p<0.05)$ higher butyric acid level and lower lactic and acetic concentrations than in haylage produced from $350 \mathrm{~g} \mathrm{DM} \mathrm{kg}^{-1}$ forage. However, all acid levels of ensilage observed in this experiment were below the concentrations reported by Hancock and Collins [75] for alfalfa round balage produced with 374 and $502 \mathrm{~g} \mathrm{~kg}^{-1}$ forage DM contents similar to ours.

Butyric acid is common in poorly fermented ensilage and it is produced from the fermentation of water-soluble carbohydrates and lactic acid, principally by Clostridia that are present on the crop at harvest. The Clostridia fermentation that usually dominates in wet forage was not evident in this experiment. Although the butyric acid levels between silage and haylage were significantly $(p<0.05)$ different, concentrations in both products did not exceed the $5 \mathrm{~g} \mathrm{~kg}^{-1}$ threshold described for poorly fermented ensilage [68]. Clostridia prefer high forage moisture concentration and high water activity for growth [31]. However, at $\mathrm{pH}$ 5.5-6.2 their growth in legume ensilage is inhibited from 350 to $500 \mathrm{~g} \mathrm{DM} \mathrm{kg}^{-1}$ forage [76]. With the relatively high ensilage $\mathrm{pH}$, we presumed that low activity of Clostridia may have resulted in relatively low levels of butyric acid in silage and haylage under the two forage DM regimes. The propionic acid concentration in good-quality ensilage is often does not exceed 2-3 g kg${ }^{-1}$ or is undetectable [19]. Confirming high fermentation quality, silage and haylage contained propionic acid levels lower than the above threshold. The higher activity of proteolytic Clostridia facilitated by high forage moisture content (350 g DM kg${ }^{-1}$ ) may have increased $\mathrm{NH}_{3}-\mathrm{N}$ in silage instead of ensiling alfalfa forage as haylage at $500 \mathrm{~g} \mathrm{DM} \mathrm{kg}^{-1}$. Despite $\mathrm{NH}_{3}-\mathrm{N}$, lactic, acetic, butyric, and propionic acid concentration differences, overall fermentation characteristics of silage and haylage were indicative of satisfactory preservation.

Aside from fermentation characteristics, it is important that alfalfa ensilage is evaluated from the perspective of animal health. Botulinum neurotoxin present in ensilage can be lethal to livestock. High initial concentration of $C$. botulinum spores in forage in combination with poor fermentation conditions promotes the growth of C. botulinum in ensilage [77]. In the two years of this study, C. botulinum serovars were not detected in the soils tested prior to the BL treatment. However, there was a variation in C. botulinum serovars in the BL used for alfalfa forage production in the 2 years. While the BL used in 2017 contained $2.02 \mathrm{ng}$ C. botulinum A, B, E, and F DNA $100 \mathrm{~g}^{-1}$ DM, none was detected in the BL applied 
in 2018. The two BL sources did not contain C. botulinum C and D serovars. In both years, C. botulinum serovars were not detected in soil after the first post-treatment forage harvest but were detected from 12 experimental plots representing the three BL treatments at the time of the second harvests. The BL used in this experiment had $360-370 \mathrm{~g} \mathrm{~kg}^{-1}$ moisture content and were in aggregate form at the time of land application. Rammer et al. [69] reported that farmyard manure aggregates applied on pasture fields can retain Clostridia and contaminate herbage at later stages. Accordingly, we presumed that the time period between BL application and first harvest might not have been adequate to establish a strong interaction between BL aggregates and soil, and thus soils were not populated with C. botulinum serovars A, B, E, and F. The absence of C. botulinum serovars A, B, E, and $\mathrm{F}$ after the first post-treatment harvest in littered soils in 2018 could be related to the absence/presence of undetectable levels of $C$. botulinum serovars in the BL. As there was a low potential for forage being contaminated through soil at harvest, we did not observe C. botulinum serovars in the ensilage from first forage harvests for the 2 years.

However, irrespective of BL treatment, ensilage from the second forage harvests contained Clostridium botulinum serovars A, B, E, and F for both the years. The ensilages contained considerably lower levels of $C$. botulinum A, B, E, and F serovars levels than observed in BL. As such, we suggest that BL used in 2018 might also have contained C. botulinum spores, but in undetectable low levels. Given the ample time to integrate with soil, $C$. botulinum propagation did occur in soil by the time of the second harvest to contaminate alfalfa plant material at ensiling. Smart et al. [78] reported a similar situation, where high numbers of $C$. botulinum were detected in uncontaminated poultry littered soil. Relun et al. [79] indicated that although BL fertilizing for silage pasture was not practiced, silage contamination could be possible by the dispersal of particles containing C. botulinum spores by wind or run-off water to the pasture fields. As there were no erected boundary barriers around the experimental plots, we suspect that C. botulinum DNA detected from the ensilage from CT plots could have originated from the cross-contamination via surface runoff. The cross-contamination phenomenon can further be supported by the lowest C. botulinum A, B, E, and F serovar concentrations detected in the CT treatment. The detection of $C$. botulinum in the ensilage from second harvest suggests that BL may require an extended time to integrate with the soil system and to proliferate in the surface soil.

Clostridium botulinum is more sensitive to $\mathrm{pH}$ values $>4.5$ and moisture concentration $>70 \%$ [31], and Notermans [80] reported that the presence of spores and botulinum toxin in grass ensilage was associated with high $\mathrm{pH}$ between 5.3 and 6.4. Although silage (350 $\left.\mathrm{g} \mathrm{DM} \mathrm{kg}^{-1}\right)$ and haylage $\left(500 \mathrm{~g} \mathrm{DM} \mathrm{kg}^{-1}\right)$ had favorable $\mathrm{pH}$ for the growth and development of Clostridia, higher concentration was detected in silage than in haylage [31]. It was also noted that there were higher ensilage C. botulinum concentrations in 2017 than in 2018, which could be related to the application of C. botulinum-contaminated BL in 2017 as compared to the application of uncontaminated BL in 2018. In general, exposure of livestock to low numbers of $C$. botulinum or spores of this microorganism is not considered harmful. As such, it is important that any factors that may induce multiplication of C. botulinum are to be avoided. Given the low concentrations of C. botulinum DNA detected in silage and haylage, we suggest that BL application at low rates (0-7.2 MG BL ha-1 or $0-112 \mathrm{~kg} \mathrm{~N} \mathrm{ha}^{-1}$ ) is not likely to pose a real threat of $C$. botulinum or may not present harmful effects on livestock feeding alfalfa silage or haylage.

\section{Conclusions}

Fertilization of BL up to 7.2 $\mathrm{MG} \mathrm{ha}^{-1}$ for alfalfa can produce 12.8-13.2 $\mathrm{MG} \mathrm{ha}^{-1}$ forage DM yield with similar nutritive value and ensilability characteristics compared to production with no fertilizer. Broiler litter fertilized alfalfa ensilage present fermentation characteristics and C. botulinum-related microbial risk levels similar to the control treatment. Alfalfa produced higher forage DM yield with superior ensilability characteristics in the second year of establishment in comparison with the first year. Broiler litter amendment increased soil nutrient accumulation risks related to $\mathrm{NO}_{3}-\mathrm{N}, \mathrm{Ca}, \mathrm{Fe}$, and $\mathrm{B}$. An intense 
accumulation of soil elements occurred in the year of alfalfa crop establishment, but levels remained unchanged in the second year. Alfalfa ensilage exhibited typical high $\mathrm{pH}$ of a leguminous forage crop and BL amendment did not affect mean fermentation quality characteristics of ensilage or C. botulinum concentrations. C. botulinum contamination occurred in BL-amended and -untreated ensilage. Silage ( $350 \mathrm{~g} \mathrm{DM} \mathrm{kg}^{-1}$ forage) had higher levels of lactic and acetic acid concentrations and other fermentation quality characteristics superior to the haylage (500 $\mathrm{g} \mathrm{DM} \mathrm{kg}^{-1}$ forage). Both silage and haylage had relatively low concentrations of $C$. botulinum, and silage contained higher levels than haylage in the first year. Broiler litter application at low rates for alfalfa forage production is an environmentally safe manure management strategy and has forage production potential, ensilage fermentative characteristics similar to the untreated form, and low C. botulinumrelated risks. Further investigation on consequences of applying higher rates of BL for alfalfa forage production and on ensilage characteristics would be beneficial for intensifying manure-based alfalfa production, conservation, and utilization among producers.

Supplementary Materials: The following are available online at https:/ / www.mdpi.com/article/ 10.3390/agronomy11040701/s1: Table S1: Mean recommended N, P, K, S, and B rates of HBL, LBL, and CT treatment plots in 2017 and 2018, Table S2: Initial soil nutrient levels of HBL, LBL, and CT treatment plots in March 2017. Table S3: Pre ensiled characteristics of 2nd cut alfalfa forages in the two years. Figure S1: Average monthly precipitation at the experimental site for 2017 and 2018, Figure S2: Daily average monthly air temperature at the experimental site for 2017 and 2018, Figure S3: Soil moisture levels at $5 \mathrm{~cm}$ depth in the experimental site for 2017 and 2018, Figure S4: Soil temperatures at $5 \mathrm{~cm}$ depth in the experimental site for 2017 and 2018.

Author Contributions: Conceptualization, P.W. and A.N.; investigation, A.N., P.W., N.R., B.G., T.W. and K.S.; writing—original draft: A.N.; writing—review and editing: P.W., B.G., T.W., N.R. and K.S. All authors have read and agreed to the published version of the manuscript.

Funding: This research was funded by the United States Department of Agriculture, through the USDA-ARS; Western Kentucky University cooperative research program.

Acknowledgments: Special thanks given to the undergraduate students William Hinton, Nick VanMeter, Alley McMillen, Meagan Walters, Brittney Hackworth, Bronson Bohannon, and Callie Whitsell who involved in the microbial laboratory analysis at the Western Kentucky University Biotechnology Center.

Conflicts of Interest: The authors declare no conflict of interest regarding the publication of this paper.

Declaration: Mention of trade names or commercial products in this publication is solely for the purpose of providing specific information and does not imply recommendation or endorsement.

\section{References}

1. Tewolde, H.; Sistani, K.R.; Rowe, D.E. Broiler Litter as a Micronutrient Source for Cotton. J. Environ. Qual. 2005, 34, 1697-1706. [CrossRef] [PubMed]

2. Adeli, A.; Sistani, K.R.; Tewolde, H.; Rowe, D.E. Broiler litter application effects on selected trace elements under conventional and no-till systems. Soil Sci. 2007, 172, 349-365. [CrossRef]

3. Evers, G.W. Comparison of broiler poultry litter and commercial fertilizer for coastal Bermuda grass production in the southeastern US. J. Sustain. Agric. 1998, 12, 55-77. [CrossRef]

4. Reddy, C.K.; Nyakatawa, E.Z.; Reeves, D.W. Tillage and Poultry Litter Application Effects on Cotton Growth and Yield. Agron. J. 2004, 96, 1641-1650. [CrossRef]

5. Mitchell, C.C.; Tu, S. Long-Term Evaluation of Poultry Litter as a Source of Nitrogen for Cotton and Corn. Agron. J. 2005, 97, 399-407. [CrossRef]

6. Han, F.X.; Kingery, W.L.; Selim, H.M.; Gerard, P.D. Accumulation of heavy metals in a long-term poultry waste-amended soil. Soil Sci. 2000, 165, 260-268. [CrossRef]

7. Soil and Water Conservation Society. Manure Management in Harmony with the Environment and Society; Soil and Water Conservation Society; West North Central Region: Ames, IA, USA, 1998.

8. Kelling, K.A.; Schmitt, M. Applying manure to alfalfa, how much and when. In Proceedings of the 26th National Alfalfa Symposium, East Lansing, MI, USA, 4-5 March 1996; pp. 92-102.

9. Albrecht, K.A.; Beauchemin, K.A. Alfalfa and Other Perennial Legume Silage; Buxton, D.R., Muck, R.E., Harrison, J.H., Eds.; Silage Science and Technology, ASA, CSA, and SSSA of America: Madison, WI, USA, 2003; pp. 633-664. 
10. Heichel, G.H.; Barnes, D.K.; Vance, C.P.; Henjum, K.I. Nitrogen fixation and N and dry matter partitioning during a 4-year alfalfa stand. Crop. Sci. 1984, 24, 811-815.

11. Gibbson, A.H. The influence of the environmental and managerial practices on the legume- Rhizobium symbiosis. In $A$ Treatise on Dinitrogen Fixation; Hardy, R.W.F., Gibson, A.H., Eds.; Wiley-Interscience: New York, NY, USA, 1977; pp. $393-498$.

12. Munns, D.N. Mineral nutrition and the legume symbiosis. In A Treatise on Dinitrogen Fixation; Hardy, R.W.F., Gibson, A.H., Eds.; Wiley-Interscience: New York, NY, USA, 1977; pp. 353-391.

13. Trimble, M.W.; Barnes, D.K.; Heichel, G.H.; Sheaffer, C.C. Forage yield and nitrogen partitioning responses of alfalfa to two cutting regimes and three soil nitrogen regimes. Crop. Sci. 1987, 27, 909-914.

14. Peterson, T.A.; Russelle, M.P. Alfalfa and the nitrogen cycle in the corn belt. J. Soil Water Conserv. 1991, 46, 229-235.

15. Phillips, D.A.; DeJong, T.M. Dinitrogen fixation in leguminous crop plants. In Nitrogen in Crop Production; Hauck, R.D., Ed.; ASA: Madison, WI, USA, 1984; pp. 121-132.

16. Cherney, J.H.; Klausner, S.D.; Duxbury, J.M. Development of Dairy Manure Management Strategies to Minimize Water Pollution; Final Report NRICGP Grant 94-37102-0988:1-10; Department of Crop and Soil Science, Cornell Univ.: Ithaca, NY, USA, 1998.

17. Lory, J.A.; Russele, M.P.; Randall, G.W. Surface applied manure effects on soil N. and N uptake, and symbiotic dinitro-gen fixation of alfalfa. In Agronomy Abstracts; ASA: Madison, WI, USA, 1992; p. 150.

18. Lanyon, L.E.; Griffith, W.K. Nutrition and fertilizer use. In Alfalfa and Alfalfa Improvement; Hanson, A.A., Barnes, D.K., Hill, R.R., Eds.; Agron Monogr. 29. ASA, CSSA, and SSSA: Madison, WI, USA, 1988; pp. 333-372.

19. Suzuki, M. Effect of stand age on agronomic, morphological, and chemical characteristics of alfalfa. Can. J. Plant Sci. 1991, 71, 445-452. [CrossRef]

20. Collins, M.; Lang, D.J.; Kelling, K.A. Effects of Phosphorus, Potassium, and Sulfur on Alfalfa Nitrogen-Fixation under Field Conditions 2. Agron. J. 1986, 78, 959-963. [CrossRef]

21. Wilkinson, J.M. Silage; Chalchombe Publications: Lincoln, UK, 2005.

22. Gordon, C.H.; Derbyshire, J.C.; Wiseman, H.G.; Kane, E.A.; Melin, C.G. Preservation and feeding value of alfalfa stored as contributes to the disadvantage of hay at feeding time hay, haylage, and direct-cut silage. J. Dairy Sci. 1961, 44, 1299-1311. [CrossRef]

23. Muller, C.E. Fermentation patterns of small- scale silage and haylage produced as a feed for horses. Grass Forage Sci. 2005, 60, 109-118. [CrossRef]

24. McDonald, P.; Henderson, A.R.; Heron, S.J.E. The Biochemistry of Silage, 2nd ed.; Chalcombe Publications: Marlow, UK, 1991.

25. Kung, L.; Stough, E.C.; Mcdonell, E.E.; Schmidt, R.J.; Hofherr, M.W.; Reich, L.J.; Kingerman, C.M. The effect of wide swathing on wilting times and nutritive value of alfalfa haylage. J. Dairy Sci. 2010, 93, 1770-1773. [CrossRef] [PubMed]

26. Smith, T.J.; Hill, K.K.; Raphael, B.H. Historical and current perspectives on Clostridium botulinum diversity. Res. Microbiol. 2015, 166, 290-302. [CrossRef]

27. Smith, L.D. Clostridium botulinum: Characteristics and Occurrence. Clin. Infect. Dis. 1979, 1, 637-641. [CrossRef]

28. Divers, T.J.; Bartholomew, R.C.; Messick, J.B.; Withlock, R.H.; Sweeney, R.W. Clostridum botulinum type B toxicosis in a herd of cattle and a group of mules. J. Am. Med. Assoc. 1986, 188, 382-386.

29. Deprz, P. Tetanus and botulinum in animals. In Clostridia in Medical, Veterinary, and Food Microbiology-Diagnose and Typing Mailnil; Dushesnes, J.C., Granum, P.E., Menozzi, M.G., Peck, M., Pelkonen, S., Popoff, M., Stackebrandt, E., Titball, R., Eds.; European Commission: Brussels, Belgium, 2006; pp. 27-36.

30. Myllykoski, J.; Lindström, M.; Keto-Timonen, R.; Söderholm, H.; Jakala, J.; Kallio, H.; Sukura, A.; Korkeala, H. Type C bovine botulism outbreak due to carcass contaminated non-acidified silage. Epidemiol. Infect. 2008, 137, 284-293. [CrossRef]

31. Payne, J.H.; Hogg, R.A.; Otter, A.; Roest, H.I.J.; Livesey, C.T. Emergence of suspected type D botulism in ruminants in England and Wales (2001 to 2009), associated with exposure to broiler litter. Vet. Rec. 2011, 168, 640. [CrossRef]

32. Muck, R.E.; Moser, L.E.; Pitt, R.E. Postharvest factors affecting ensiling. In Silage Science and Technology; Buxton, D.R., Muck, R.E., Harrison, J.H., Eds.; American Society of Agronomy: Madison, WI, USA, 2003; pp. 251-304.

33. Carter, A.T.; Peck, M.W. Genomes, neurotoxins and biology of Clostridium botulinum Group I and Group II. Res. Microbiol. 2015, 166, 303-317. [CrossRef]

34. Withlock, R.H.; William, J.M. Botulism toxicosis of cattle. Proc. Bov. Pract. 1999, 32, 45-53.

35. Kelch, W.J.; Kerr, L.A.; Pringle, J.K.; Rohrbach, B.W.; Withlock, R.W. Fatal Clostridium botulinum toxicosis in eleven Holstein cattle fed round bale barley haylage. J. Vet. Diagn. Investig. 2000, 12, 453-455. [CrossRef]

36. Johnson, A.L.; Sweeney, R.W.; McAdams, S.C.; Whitlock, R.H. Quantitative real-time PCR for detection of the neurotoxin gene of Clostridium botulinum type B in equine and bovine samples. Vet. J. 2012, 194, 118-120. [CrossRef]

37. Sobel, J.; Tucker, N.; Sulka, A.; McLaughlin, J.; Maslanka, S. Foodborne Botulism in the United States, 1990-2000. Emerg. Infect. Dis. 2004, 10, 1606-1611. [CrossRef] [PubMed]

38. Cabrera, M.I.; Gordillo, R.M. Nitrogen release from land applied animal manuers. In Animal Waste and Land Water Interface; Steel, K., Ed.; CRC Lewis Publ.: New York, NY, USA, 1995; pp. 393-403.

39. Mehlich, A. Mehlich 3 soil test extractant: A modification of Mehlich 2 extractant. Commun. Soil Sci. Plant Anal. 1984, 15, 1409-1416. [CrossRef] 
40. Mulvaney, R.I. Analysis N: Inorganic forms. In Methods of Soil Analysis Part 3: Chemical Methods; Sparks, D.L., Page, A.L., Helmke, P.A., Loeppert, R.H., Soltanpour, P.N., Tabatabai, M.A., Johnston, T., Summer, M.E., Eds.; SSSA: Madison, WI, USA, 1994; pp. 1123-1184.

41. Farmer, G.S.; Brusewitz, G.H. Use of Home Microwave Oven for Rapid Determination of Moisture in Wet Alfalfa. Trans. ASAE 1980, 23, 170-172. [CrossRef]

42. Kung, L.; Ranjit, N. The Effect of Lactobacillus buchneri and Other Additives on the Fermentation and Aerobic Stability of Barley Silage. J. Dairy Sci. 2001, 84, 1149-1155. [CrossRef]

43. Goldenberger, D.; Perschil, I.; Ritzler, M.; Altwegg, M. A simple "universal” DNA extraction procedure using SDS and proteinase $\mathrm{K}$ is compatible with direct PCR amplification. Genome Res. 1995, 4, 368-370. [CrossRef] [PubMed]

44. Wang, X.; Teng, D.; Tian, F.; Guan, Q.; Wang, J. Comparison of Three DNA Extraction Methods for Feed Products and Four Amplification Methods for the 5'-Junction Fragment of Roundup Ready Soybean. J. Agric. Food Chem. 2012, 60, 4586-4595. [CrossRef] [PubMed]

45. Daliparthy, J.; Herbert, S.J.; Veneman, P.L.M. Dairy Manure Applications to Alfalfa: Crop Response, Soil Nitrate, and Nitrate in Soil Water. Agron. J. 1907, 86, 927-933. [CrossRef]

46. Lloveras, J.; Arán, M.; Villar, P.; Ballesta, A.; Arcaya, A.; Vilanova, X.; Delgado, I.; Munoz, F. Effect of Swine Slurry on Alfalfa Production and on Tissue and Soil Nutrient Concentration. Agron. J. 2004, 96, 986-991. [CrossRef]

47. Coblentz, W.K.; Muck, R.E.; Borchardt, M.A.; Spencer, S.K.; Jokela, W.E.; Bertram, M.G. Effects of dairy slurry on silage fermentation characteritics and nutritive value of alfalfa. J. Dairy Sci. 2014, 97, 7197-7211. [CrossRef]

48. Lory, J.; Kallenbach, R.; Roberts, C. Managing Manure on Alfalfa Hay; MU Guide G 4555; University of Missouri-Columbia Extension. Services: Columbia, SC, USA, 2000.

49. Schmitt, M.A.; Sheaffer, C.C.; Randall, G.W. Manure and fertilizer effects on alfalfa plant nitrogen and soil nitrogen. J. Prod. Agric. 1994, 7, 104-109. [CrossRef]

50. Mathers, A.C.; Stewart, B.A.; Blair, B. Nitrate-nitrogen removal from soil profile by alfala. J. Environ. Qual. 1975, 4, 403-405. [CrossRef]

51. University of Kentucky Cooperative Extension. Fertilizer Management in Alfalfa. AGR-210. University of Kentucky Cooperative Extension. 2004. Available online: http://www2.ca.uky.edu/agcomm/pubs/AGR/AGR210/AGR210.pdf (accessed on 12 January 2021).

52. Hojjati, S.M.; Templeton, W.C.; Taylor, T.H. Nitrogen Fertilization in Establishing Forage Legumes 1. Agron. J. 1978, 70, 429-433. [CrossRef]

53. Schertz, D.L.; Miller, D.A. Nitrate-N Accumulation in the Soil Profile Under Alfalfa 1. Agron. J. 1972, 64, 660-664. [CrossRef]

54. Kelling, K.A.; Matocha, J.E. Plant analysis as an aid in fertilizing forage crops. In Soil Testing and Plant Analysis; Westerman, R.L., Ed.; SSSA Book Ser. 3; SSSA: Madison, WI, USA, 1990; pp. 603-643.

55. Cherney, J.H.; Cherney, D.J.R.; Bruulsema, T.W. Potassium management. In Grass for Dairy Cattle; Cherney, J.H., Cherney, D.J.R., Eds.; CAB International: Wallingford, UK, 1998; pp. 147-148.

56. Goff, J.; Horst, R. Effects of the Addition of Potassium or Sodium, but Not Calcium, to Prepartum Rations on Milk Fever in Dairy Cows. J. Dairy Sci. 1997, 80, 176-186. [CrossRef]

57. Min, D.H.; Vough, L.R.; Reeves, J.B. Dairy slurry effects on nutritive value of orchard grass, reed canarygrass, and alfalfa grass mixtures. Anim. Feed Sci. Technol. 2002, 95, 143-157. [CrossRef]

58. Schmidt, R.; Hu, W.; Mills, J.; Kung, L. The development of lactic acid bacteria and Lactobacillus buchneri and their effects on the fermentation of alfalfa silage. J. Dairy Sci. 2009, 92, 5005-5010. [CrossRef]

59. Buxton, D.R.; O'Kiely, P. Preharvest Plant Factors Affecting Ensiling; Buxton, D.R., Muck, R.E., Harrison, J.H., Eds.; Silage Science and Technology, ASA, CSSA, and SSSA: Madison, WI, USA, 2003; pp. 199-250.

60. Jackson, B.; Seaman, J.; Bertsch, P. Fate of arsenic compounds in poultry litter upon land application. Chemosphere 2006, 65, 2028-2034. [CrossRef] [PubMed]

61. Netthisinghe, A.M.P.; Gilfillen, R.A.; Willan, T.W.; Rowland, N.S.; Sistani, K.R. Inorganic fertilizers after broiler litter amendment reduce surplice nutrients in orchard grass soil. Agron. J. 2011, 103, 536-543. [CrossRef]

62. Evers, G.W. Ryegrass-bermudagrass production and nutrient uptake when combining nitrogen fertilizer with broiler litter. Agron. J. 2002, 94, 905-910. [CrossRef]

63. Lucero, D.W.; Martens, D.C.; McKenna, J.R.; Starner, D.E. Poultry litter effects on unmanaged pasture yield, nitrogen and phosphorus uptakes, and botanical composition. Commun. Soil Sci. Plant Anal. 1995, 26, 861-881. [CrossRef]

64. Vervoort, R.W.; Radcliffe, D.E.; Cabrera, M.L.; Latimore, M. Field-Scale Nitrogen and Phosphorus Losses from Hayfields Receiving Fresh and Composted Broiler Litter. J. Environ. Qual. 1998, 27, 1246-1254. [CrossRef]

65. Wood, C.W.; Torbert, H.A.; Delany, D.P. Poultry litter as a fertilizer for bermudagrass: Effects on yield and quality. J. Sustain. Agric. 1993, 3, 21. [CrossRef]

66. Rammer, C.; Lingvall, P. Influence of farmyard manure on the quality of grass silage. J. Sci. Food Agric. 1997, 75, 133-140. [CrossRef]

67. Kingery, W.L.; Wood, C.W.; Delaney, D.P.; Williams, J.C.; Mullins, G.L.; Van Santen, E. Implications of Long-Term Land Application of Poultry Litter on Tall Fescue Pastures. J. Prod. Agric. 1993, 6, 390-395. [CrossRef]

68. Mahanna, B.; Chase, L.E. Practical applications and solutions to silage problems. Silage Sci. Technol. 2003, 42, 55-895. 
69. Rammer, C.; Östling, C.; Lingvall, P.; Lindgren, S. Ensiling of manured crops-effects on fermentation. Grass Forage Sci. 1994, 49, 343-351. [CrossRef]

70. Pitt, R.E.; Muck, R.E.; Leibensperger, R.Y. A quantitative model of the ensilage process in lactate silages. Grass Forage Sci. 1985, 40, 279-303. [CrossRef]

71. Kibe, K.; Noda, E.; Karasawa, Y. Effect of moisture level of material grass on silage fermentation. Shinshu Univ. J. Fac. Agric. 1981, $18,145-154$.

72. Dewar, W.A.; McDonald, P.; Whittenbury, R. The hydrolysis of grass hemicelluloses during ensilage. J. Sci. Food Agric. 1963, 14, 411-417. [CrossRef]

73. Melvin, J. Variations in the carbohydrate content of lucerne and the effect on ensilage. Aust. J. Agric. Res. 1965, 16, 951-959. [CrossRef]

74. Muck, R.E. Dry matter level effects on alfalfa silage quality II. Fermentation products and starch hydrolysis. Trans. ASAE 1990, 33, 373-381. [CrossRef]

75. Hancock, D.; Collins, M. Forage Preservation Method Influences Alfalfa Nutritive Value and Feeding Characteristics. Crop. Sci. 2006, 46, 688-694. [CrossRef]

76. Leibensperger, R.Y.; Pitt, R.E. A model of clostridial dominance in ensilage. Grass Forage Sci. 1987, 42, 297-317. [CrossRef]

77. Driehuis, F.; Wilkinson, J.; Jiang, Y.; Ogunade, I.; Adesogan, A. Silage review: Animal and human health risks from silage. J. Dairy Sci. 2018, 101, 4093-4110. [CrossRef] [PubMed]

78. Smart, J.L.; Jones, T.O.; Clegg, F.G.; McMurtry, M.J. Poultry waste associated type C botulism in cattle. Epidemiol. Infect. 1987, 98, 73-79. [CrossRef]

79. Relun, A.; Dorso, L.; Douart, A.; Chartier, C.; Guatteo, R.; Mazuet, C.; Popoff, M.R.; Assie, S. A large outbreak of bovine botulism possibly linked to a massive contamination of grass silage by type D/C Clostridium botulinum spores on a farm with dairy and poultry operations. Epidemiol. Infect. 2017, 145, 3477-3485. [CrossRef]

80. Notermans, S.; Dufrenne, J.; Oosterom, J. Persistance of Clostridium botulinum type B on a cattlefarm afteran outbreak of botulism. Appl. Environ. Microbiol. 1981, 41, 179-183. [CrossRef] 